\title{
HET ANIMISME BIJ DEN MINANGKABAUER DER PADANGSCHE BOVENLANDEN
}

DOOR

\author{
J. L. VAN DER TOORN.
}

Onder den titel van: "Het animisme bij de volken van den Indischen Archipel", geeft Dr. G. A. Wilken, in de jaargangen 1884 en 1885 van "de Indische Gids", een schets, die den lezer op de meest onderhoudende wijze in kennis brengt met den natuurgodsdienst van de O. I. Archipel-bewoners. Het was dan ook niet met de bedoeling, om af te dingen op de volledigheid van een opstel, van zooveel studie getuigende, dat ik deu lezer de volgende aanteekeningen aanbied. Ik ging er alleen toe over in het denkbeeld, dat het aan Dr. Wilken en verder aan allen, die genoemde schets lazen, welgevallig kon zijn, indien er nog een en ander werd medegedeeld omtrent het animisme en zijne twee hoofddogmen, het fetisisme en het spiritisme, bij de Minangkabau-Maleiers van de Padangsche Bovenlanden.

Dualisme van de ziel. - Lykanthropie. - Heksengeloof. - De ziel bij dieren, planten en levenlooze voorwerpen. - Het voortbestaan der ziel na den dood. - Zielsverhuizing (wedergeboorte). - Verwantschap tusschen den mensoh en het dier. - Doodenoffers en doodenfeesten.

Evenals bij de andere volkeren in den Indischen Archipel, treft men bij den Minangkabauer - Dr. Wilken wees er reeds op het begrip aan, dat de mensch in het bezit is van een $\mathrm{nja}$ o- en een soemang ès 1 , of, zooals hij zich meermalen uitdrukt, van een

1 es vertegenwoordigt de uitspraak van den uitgang at. 
nja ŏ nan sabananŏ, d. i. een werkelijke, ware ziel, en een nja ŏ réhan, d. i. een ziel, die verdwijnt, afwezig zijn kan. Terwijl de eerste beschouwd wordt het levensbeginsel, het leven of de adem te zijn, wordt de laatste genomen voor datgene, wat wij levenskracht, levensvuur, bewustzijn noemen. De soemang è ${ }^{\text {s }}$ is het, die den indruk veroorzaakt, vrees, eerbied en bewondering opwekt; kracht, luister en levendigheid aan het voorkomen geeft, en zich alzoo openbaart in de uitdrukking van het gelaat, in de houding en beweging van het lichaam. Ieder gezond mensch kan de Minangkabauer een oerang ba soe mang è noemen, maar liever zegt hij dat van iemand, die er flink en krachtig uitziet, die imponeert of levendig en opgewekt is. Van hem, die een zwak of ziekelijk voorkomen of weinig of geen uitdrukking in het gelaat heeft, heet het la ma h soeman-

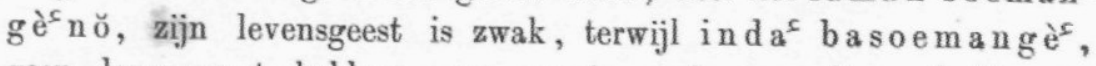
geen levensgeest hebben, een groote mate van uitgeputheid aanduidende, den levensgeest als afwezig veronderstelt.

De soemang ̀̀s, zoowel als de nja o, is onstoffelijk; tusschen hen beiden bestaat een immige verwantschap; maar ten opzichte van het stoffelijk omhulsel is hunne verhouding versehillend. Terwijl dit latste toch, zoodra de nja ó is heengevloden, an vernietiging is prijs gegeven, wordt de toestand van een lichaam, door de afwezigheid van zijn soemang $\mathrm{e}^{\mathrm{s}}$, alleen gewijzigd. Slechts dan wanneer de soemangat in 't geheel niet terugkeert, moet ook alle leven in het lichasm ophouden.

Gaan wij vooreerst na, wat, volgens de opvatting van den Minangkabauer, de soemangat is. Deze, zegt hij, is een wezen, dat met bewustheid handelt, dat een wil, een denk- en gevoelvermogen bezit, en wiens bestaan van het lichaam geheel onafhankelijk is. Terwijl haar aanwezig-zijn aan het lichaam kracht, aan de bewegingen levendigheid, aan 't oog gloed en leven, en aan 't gelaat kleur en uitdrukking geeft; verdwijnt dit alles, wanneer zij haren zetel heeft verlaten, in welke oogenblikken zij-zelve lijdende, doch ook in groote vreugde kan zijn. Haar heengaan en terugkeeren geschiedt vrijwillig of gedwongen.

Een vrijwillig afzijn bespeurt men bij het droomen, wanneer de soemangat verwijlt op plaatsen of bij voorwerpen, die des daags een diepen indruk op iemand gemaakt hebben, en waarbij in sommige gevallen de hardop pratende slaper datgene openbaart, wat de soemangat, die aan het ronddwalen is, ontmoet en bespreekt. Op deze afwezigheid volgt een vrijwillig terugkeeren. Eigenaardig is hierbij 
de beschouwing, dat het hoogst onvoegzaam is, het gelaat van een slapende zwart te maken of te bemorsen, daar de soemangat afkeer zou kunnen gevoelen, om in zulk een lichaam terug te keeren, en die persoon dus zou kunnen sterven.

Een gedwongen afziju van de soemangat openbaart zich b. v. bij schrik, angst en ziekte. De eerste wordt veroorzaakt door de plotselinge ontmoeting van de soemangat met een andere, die zij in 't geheel niet verwacht heeft, of die haar geheel vreemd is, en wier tegenwoordigheid haar noopt, het lichaam te ontvluchten. Ook hier volgt een wederkeeren uit eigen beweging, zoodra het onverwachte of vreemde van de ontmoeting voorbij, of de onbekende soemangat heengegaan is. Angst kan eveneens het gevolg van zulk eene ontmoeting zijn, maar ook veroorzakt worden door het vonrgevoel, dat de soemangat van een naderend onheil heeft. Wij zien dit b. v. bij den misdadiger, die ter doodstraf wordt geleid, en wiens bleek gelaat en bevend lichaam aantoonen, dat de soemangat reeds is heengegaan. Ziekte ontstaat door de plagerijen, die booze geesten een door haar medegevoerde soemangat aandoen; zij is de openbaring van het leed en de pijnen, die de soemangat te verduren heeft, en die zich aan het lichaam van den patient mededeelen. Het lijden is van korteren of langeren duur, van minder of meer ernstigen aard, naar gelang van den tijd, dien de soemangat in gevangenschap doorbrengt, en van de kwellingen, waaraan zij is blootgesteld. Het terugkeeren geschiedt hier vrijwillig of gedwongen.

Zooals blijkt, noemt de Minangkabauer als uitingen van het afzijn van de soemangat juist die toestanden, slaap, schrik, angst, ziekte, waarbij leven, beweging, uitdrukking, enz., ontbreken, en schrijft hij het terugkrijgen van dit alles an hare tehuiskomst toe. Hilang soemang ̀̀s nŏ, dat eigenlijk beteekent: zijn bewustzijn of levensgeest is gevloden, wordt daarom dan ook gebruikt in den zin van: hij is ontsteld, hij is verschrikt of beangst, aangezien deze toestanden het gevolg zijn van het afwezen der soemangat.

Als oorzaak voor dat afzijn hoorde ik o. a. nog het volgende vertellen. Iemand kan zich den toorn van een boozen geest op den hals gehaald hebben, omdat hij hem onder 't loopen uit den weg heeft gestooten, of omdat hij hem getrapt, of zijn huis, tuin of speelplaats verwoest heeft. In zulk een geval makt de booze geest zich van de soemangat van dien persoon meester en houdt haar onder allerlei mishandelingen gevangen. Een booze geest kan echter ook liefde of toegenegenheid voor iemand opgevat hebben. Zoolang 
hij nu in de gelegenheid is dien persoon te ontmoeten, zal hij diens soemangat niet rooven; maar begeeft het voorwerp van zijn liefde of toegenegenheid zich naar elders, dan maakt de geest zich van de soemangat meester en behandelt haar als zijns gelijke. Zoo laat hij b. v. de soemangat van een kind met zijn eigen kroost spelen en deelt haar versnaperingen en snuisterijen mede. Men ziet het dus, de soemangat heeft menschelijke zintuigen, zij heeft besef zoowel van het leed als van de genietingen des levens.

De terugkeer van de soemangat in het menschelijk lichaam kan, gelijk reeds werd opgemerkt, niet alleen vrijwillig, doch ook gedwongen zijn, met andere woorden de soemangat kan in het lichaam worden teruggebracht. Hierbij speelt de doekoen (mannelijke of vrouwelijke geneeskundige) een voorname rol. De Minangkabauer vertelt daaromtrent het volgende.

Indien er iemand ziek is, wordt de doekoen gehaald, en voor haar (we hebben met eene vrouw te doen) de volgende ingrediënten klaar gemaakt:

1. Siriĕh langk ŏ de bijnerven op dezelfde plaats aan de hoofdnerf samenkomen. Langs de nerven wordt het blad met een mes verdeeld, zoodanig dat de stukken aan de hoofdnerf blijven vastzitten. Van elk deel wordt, door toevoeging van jonge pinang, gambir en kalk, een betelpruimpje gemakt, sirih baransi geheeten;

2. de bloem van de sipangiě-pangi ̌̆;

3 . batiěh, d. i. nat gemaakte en daarna geroosterde rijst, die goed heen en weer geschud wordt;

4. a mpiĕng, rijst die vochtig gemaakt, verwarmd en vast ineen gestampt wordt;

5. a loe ŏ, rijst, die eerst geroosterd, daarna fijn gemaakt en vervolgens met stroop vermengd wordt;

6. zooveel gekookte kippeneieren als het aantal personen bedraagt, wier soemangat teruggehaald moet worden. Ieder ei wordt overlangs in twee helften gesneden;

7. gewoon gekookte rijst;

8. zeven pitih sirah, d. i. zoowat zes centen.

Deze zaken worden klaar gemaakt door een reine vrouw, d. w. z. door een vrouw, die op dat oogenblik geen menstruatie heeft, en op een eenigszins verheven plaats gelegd, waarna de doekoen in een parasapan - een schaal met gloeiende kolen - wat benzoë ontsteekt en deh djihins, geesten, met wie zij bevriend is, onder 
het opnoemen van hun namen en woonplaatsen, aankondigt, wat hare bedoeling is, hen verzoekende, haar in het opsporen van den verloren levensgeest behulpzaam te willen zijn en dezen naar de woning van den patient terug te brengen. De doekoen gaat nu liggen en wordt dichtgedekt met een deken. Ongeveer een kwartier later bespeurt men aan het trillen harer beenen, dat hare soemangat het lichaam verlaten heeft en op reis is naar de kampoeng der djihins. Daar aangekomen, vertelt zij aan haar vrienden en vriendinnen, wat de reden is van haar bezuek (dit hoort men echter niet), waarop de oudste der vrouwelijke djihins - M andé Ro ebià h - met eenige volgelingen, waaronder ook mannelijke, om den roover van de soemangat ontzag in te boezemen, de gevangene gat zoeken. Somtijds, d. i. in een ernstig ziektegeval, bedingt de booze geest voor de teruggave een offer, en, als onderpand voor het nakomen eener gedane belofte daaromtrent, een armband, kris of andere kostbaarheid. Die voorwerpen worden voor dat doel dan ook dikwijls aan de doekoen afgestaan. Gelukt het Mandé Roebiah niet de soemangat terug te krijgen, dan lijdt het geen twijfel of de patient zal sterven. Wordt zij haar echter afgestaan, dan brengt zij haar onder geleide van een groot gevolg, dat haar tegen de aanrandingen van nieuwe roovers moet beveiligen, terug en het herstel van den zieke'mag alsdan verwacht worden. De komst der djihins, die den levensgeest terugvoeren, wordt aangekondigd door nieuwe trillingen in de beenen der doekoen die zelve echter - haar soemangat nl. - nog in de kampoeng achtergebleven is. De stemgeluiden, welke van onder de deken gehoord worden, worden dan ook gezegd van de in de doekoen gevaren djihins te zijn. De djihins verzoeken een titihan - balk of plank of iets dergelijks als overloop boven een diepte - klaar te maken, d. i. in dit geval een verzoek om wat benzoë te branden, ten einde de soemangat, die nu op de trap staat, te verwelkomen. Aan de vreemde gasten wordt tevens verzocht van de klaargezette spijzen en sirihpruimpjes te willen nuttigen, waarna Mandé Roebiah aan de vrouwelijke djihins gelast, den levensgeest in het lichaam terug te brengen. Deze djihins doen dat onder het opdreunen van de volgende pantoens:

Baboeah-boeah si lakoei ${ }^{\varsigma}$ Baboeah doeŏ poeloeăh Soemangè lah kami djapoeis Badiri kabatang toeboeăh
De lakoep (een wilde mangga) draagt v ruchten; Zij draagt er zeven en twintig ;

Den levensgeest hebben wịj gehaald;

Hij zetelt in het lichaam. 
Baboeah-boeah si lakoei ${ }^{\varsigma}$ Baboeah sa kampiě baih Soemangè $^{\varsigma}$ lah kami djapoei ${ }^{\varsigma}$ Badiri kadjari manih

Baboeah-boeah si lakoeis Baboeah sa kampiĕ pandan Soemangè ${ }^{\varsigma}$ lah kami djapoei ${ }^{\varsigma}$ Badiri ka indoeà tangan

Baboeah-boeah si lakoei ${ }^{\text {s }}$ Baboeah sa kampiě padi

Soemangès lah kami djapnei ${ }^{\varsigma}$ Badiri ka indoed kaki

Baboeah-boeah si lakoeis Baboeah doeǒ poeloeăh asŏ Soemangè lah kami djapoei ${ }^{\varsigma}$ Badiri ka oerang-oerang matŏ
De lakoep draagt vruchten;

Zij draagt er een mandje vol;

Den levensgeest hebben wij gehaald;

$\mathrm{Hij}$ zetelt in den ringvinger.

De lakoep draagt vruchten;

$\mathrm{Zij}_{\mathrm{ij}}$ draagt er een mandje vol;

Den levensgeest hebben wij gehaald:

Hij zetelt in den duim.

De lakoep draagt vruchten;

$\mathrm{Zij}$ draagt er een mandje vol;

Den levensgeest hebben wij gehaald;

Hij zetelt in den grooten toon.

De lakoep draagt vruchten;

Zij draagt er een en twintig;

Den levensgeest hebben wij gehaald;

Hij zetelt in de pupil van 't oog.

$\mathrm{Na}$ afloop van dit alles, vraagt men gewoonlijk nog aan Mandé Roebiah, waar de soemangat vertoefd heeft, wat men voor den lijder nog verder doen moet, en welke geneesmiddelen men hem zal ingeven; en dikwijls raadt deze geest dan aan, dat men een bad zal maken met limau manih er in, waarin de zieke zich, met het gelaat naar den eenen of anderen berg gekeerd, vóór 12 uur, moet wasschen, en verder, dat men op eene door haar aangeduide plaats, in de avondschemering, een ataran zal neerzetten, bestaande uit een gekookt kippenei, in twee helften gesneden, rijst, sirih en tabak, waarnevens wat benzoë wordt gebrand. Deze ataran is dan het aan den plaaggeest beloofde offer. Mandé Roebiah bepaalt ook de geneesmiddelen, of zegt, dat men zich daarvoor tot de doekoen wenden moet. Deze schrijft dan de medicijnen voor, maar meestal niet terstond na het terugbrengen der soemangat, aangezien zij op dat oogenblik nog te vermoeid is, zooals blijkt als zij uit hare bezwijming is bijgekomen.

Het is hier de meest geschikte plaats, om, alvorens verder te gaan, nog het een en ander over deze doekoens en hare practijken te zeggen. Gelijk uit het medegedeelde te bespeuren is, is de doekoen, die hare soemangat uitzendt om de djihins te halen en die later door deze djihins bezeten wordt, welke door haren mond spreken, een shaman ${ }^{1}$.

1 Hierover leze men: Het shamanisme bij de volken van den Indischen archipel door Dr. G. A. Wilken, Bijdragen tot de T. L. en Vk. van Ned. Indië, vijfde volgreeks, dl. II, blz. 427 vv. 
Vandaar dan ook de benaming oerang kapitoeroenan - van to eroen $=$ dalen, nederdalen, dus: persoon in wien geesten plegen neder te dalen - waaronder de doekoens ook bekend zijn. Niet altijd echter geschiedt de ziektebezwering op de zooeven vermelde wijze. Somtijds n.l. gaat de doekoen voor dat doel achter een koelamboe (gordijn) staan, na vooraf den patient, die zijn hulp kwam inroepen, en alle personen, die bij hem mochten zijn, ernstig op het hart gedrukt te hebben, bij alles wat zij zien of hooren mochten, een diep stilzwijgen te bewaren. $\mathrm{Na}$ eenige oogenblikken verschijnen er voor den doekoen achter het gordijn een of meer met hem bevriende geesten, en hoort men hem dezen over het ziektegeval raadplegen. Daarna komt de doekoen weêr te voorschijn, om den zieke te vertellen, waar deze ongesteld geworden is, en hem de noodige geneesmiddelen te geven, die hij bespuwt en waarover hij een tooverformule uilspreekt. Aangezien de Minangkabauer zegt, dat, tijdens de conferentie achter het gordijn, niet de stem van den geest, maar wel die van den doekoen gehoord wordt, heeft men blijkbaar in dit geval niet te doen met een persoon, in wien de geesten nederdalen, doch met iemand, die de geesten oproept ten einde hen te raadplegen.

Hoezeer men hecht aan het geloof, dat de soemangat een tijdlang buiten het lichaam kan rondwaren, vindt men bevestigd in het sprookje van den hantoe haroe-haroe ${ }^{1}$. Het gebeurt wel eens, zoo vertelt de Minangkabauer, dat iemand, in de duisternis onderweg zijnde, een geheimzinnig persoon tegenkomt, die veel gelijkenis heeft met zijn broer of oom of met een van zijn goede kennissen. Deze noodigt hem nit, hem te volgen naar zijn huis of naar een of ander feest. Voldoet hij daaraan, dan vindt hij zich eensklaps geplaatst in een wonderland, vol breede wandelwegen en schoone bosschen, waar de geur van de welriekendste bloemen hem tegenwaait. Verre, verre wordt hij door den dwaalgeest, han toe haroe-h a roe, weggevoerd, totdat hij ankomt in een fraaie kampoeng, met prachtige huizen, speel- en badplaatsen. Schoone vrouwen en levenslustige jongelingen verwelkomen hem. Ruiters, op weelderige paarden gezeten, galoppeeren er in de sierlijkste wendingen, en ook hij ontvangt een vurig ros, om het te berijden. Frissche maagden maken er de welluidendste muziek en noodigen hem tot meedoen uit ; dansers en danseressen bewegen er zich, op

${ }^{1} \mathrm{Hanto \theta}=$ geest, gewoonlijk : booze geest, spook; $-\mathrm{h}$ a roe $=\mathrm{I}$. verontrusten, storen; II. naam van een boom. Sommigen leiden den naam van de eerste, anderen van de tweede beteekenis af. 
de maat der heerlijkste tonen, met lichte en losse bewegingen in 't rond. Door gulhartige gastheeren wordt hij onthaald op spijzen en dranken, wier geur en smaak hem geheel onbekend zijn. Gaarne zou hị in dit schoone feeënoord willen blijven. - - Wij hebben hier met niets anders te doen, dan met een droom onder een bijzonderen vorm, zooals blijkt uit hetgeen de Minangkabauer verhaalt omtrent het opsporen van zulk een betooverde. Deze wordt namelijk opgezocht onder het slaan op verschillende instrumenten, zooals de gandang, tjèn ang, enz., waarbij men onophoudelijk zijn naam uitschreeuwt, door welk rumoer hij dan ook weer tot zijn zinnen komt. Gewoonlijk wordt hij gevonden onder een grooten boom of in het kreupelhout.

Dat de soemangat het lichaam kan verlaten en daarin terugkeeren, is een opvatting, waarop het zoogenaamde manggasiěng 1 berust, een tooverij, die vaak wordt toegepast door wraakzuchtige minnaars. Deze namelijk hebben de overtuiging, dat zij door die tooverij de hulp kunnen erlangen van booze geesten, om de soemangat weg te voeren van de vrouw, die hen afwees, en haar zoodoende in een toestand van razernij te brengen, die bekend is onder den naam van $\mathrm{Si} \mathrm{Djoendai}{ }_{2}$ en veelvuldig onder de vrouwen in de $\mathrm{Pa}$ dangsche Bovenlanden wordt aangetroffen. Voor dat doel zoekt hij in 't bezit te komen van het voorhoofdsbeen, $t$ angkoeras, van een gestorven oerang barani 3 of oerang barélémoe ${ }^{4}$, en van eenige hoofdharen zijns slachtoffers. Aan dat been geeft hij den vorm van een schijf; hij windt er de haren om heen en boort er een paar gaten in, zoodat het werktuigje door het heen en weer trekken aan een koord, dat door de openingen gebracht is, een snorrend geluid voortbrengt. Met deze gasiěng, waarover een tooverspreuk wordt uitgesproken, begeeft hij zich, gewoonlijk des avonds, naar de eene of andere heilige plaats in het bosch, waar hij, aan het koord trekkende, voor zijn doel de hulp der geesten inroept. Is zijn toeleg gelukt, dan begint de vrouw te lijden aan vlagen van krankzinnigheid, die zich in zulk eene woestheid openbaren, dat zij gillend overal tegen opklimt en de kleederen zich van het lichaam rukt of

${ }^{1} \mathrm{Gasiěng} \mathrm{is} \mathrm{een} \mathrm{speeltuigje,} \mathrm{bestaande} \mathrm{uit} \mathrm{een} \mathrm{plat} \mathrm{sohijfje} \mathrm{van} \mathrm{been} \mathrm{of} \mathrm{iets}$ dergelijks, met twee gaatjes er in. In deze gaatjes wordt een koord gestoken, waaraan getrokken wordt, om het werktuigje in beweging te brengen en een snorrend geluid te laten maken.

${ }^{2} \mathrm{Si} \mathrm{Djoendai} \mathrm{is} \mathrm{ook} \mathrm{de} \mathrm{naam} \mathrm{van} \mathrm{het} \mathrm{toovermiddel-zelf.}$

3 Oerang $=$ mensch, persoon; barani $=$ dapper, stoutmoedig.

4 Oerang barélémoe beteekent gewoonlijk: iemand, die allerlei kunstenarijen kent. 
stuk scheurt, daarbij onophoudelijk den naam van haren minnaar uitroepende. Het eenige middel om dezen toestand te doen ophouden, is dat een der bloedverwanten van de betooverde, insgelijks door toedoen van het manggasiěng, de booze geesten terugdrijít of hen overhaalt, de soemangat van den belager eveneens te kwellen.

De Si Djoendai $\mathrm{Paka}^{\varsigma_{1}}$ is een dergelijke ziekte, die echter niet door het manggasiěng ontstaat, maar door het eten van allerlei vuiligheid, die de afgewezen minnaar de vrouw heeft weten te bereiden 2.

Een ander gebruik, dat op deze opvatting wijst, is het zoogenaamde maninga m, dat in 't kort hierop nederkomt. Wanneer iemand zijn wrok niet koelen kan of zijne liefde op den duur onbeantwoord ziet, roept hij de hulp in van een oerang barélémoe om het voorwerp zijner haat of wanhopige liefde de tingg am te bezorgen. Nadat hij den toovenaar de noodige inlichtingen heeft gegeven omtrent naam, gedrag, lichaamsgestalte, woonplaats en familie van de bewuste persoon, makt hij een pop, die het slachtoffer moet voorstellen, en begeeft zich daarmede naar het woud, waar hij de beeltenis aan een geheel alleen staanden boom ophangt. Onder het prevelen eener tooverformule steekt hij dan door den navel der pop zoolang in den boom, dat het sap van dezen door de ontstane opening heendringt. Dit sap is, volgens de voorstelling, de soemangat van het slachtoffer. Spoedig daarna openbaart zich bij dit laatste de ting ga m ${ }^{2}$, die hoe langer hoe erger wordt, en alleen genezen kan, wanneer het aan de bloedverwanten gelukt, een stuk hout van bedoelden boom machtig te worden. Slagen zij daarin niet, dan moet de zieke sterven.

Bestaan er, zooals wij uit 't bovenstaande zien, middelen om een afwezige soemangat in het lichaam terug te voeren, men kan ook in sommige gevallen haar heengaan voorkomen. Vandaar dat men bij voorbeeld een kraamvrouw somtijds een streng garen of een koord om den pols of de lendenen bindt. De soemangat, die ontvluchten wil, vindt hierdoor den aftocht gesloten.

Wij komen nu tot de vraag, in welken vorm of in welke gedaante de levensgeest het lichaam verlaat. De opvatting daaromtrent is verschillend. Bij de meesten treft men heden zelfs de meening aan, dat de geest, iets onstoffelijks zijnde, geen vorm of gedaante bezit. Dat echter

\footnotetext{
${ }^{1} \mathrm{Paka}^{5}=$ doof, harthoorend, dof, klankloos. Si Djoendai Pakas is ook de naam van het toovermiddel-zelf.

2 Tinggam is een soort van booze zweer, ook de naam van het voorwerp, waarmede in de beeltenis of pop gestoken wordt.
} 
vroeger eene andere beschouwing ook bij den Minangkabauer moet hebben bestaan, blijkt 0 . a. nit den inhoud van bovenaangehaalde pantoens, en uit het gezegde "de soemangat staat op den trap", waarmede haar terugkomst in de woning van een zieke wordt aangekondigd. Terwijl sommige doekoens verder beweren, dat de soemangat heengaat en terugkeert als homunculus, zijn andere van gevoelen, dat dit geschiedt als rangi ${ }^{\varsigma}$, vlieg, en vandaar het gebruik om spijzen klaar te zetten, ten einde haar wederkeeren te bewerkstelligen. De eerste $\mathrm{rangi}^{5}$, die zich daarop nederzet, wordt als de ontvloden levensgeest beschouwd.

Een ander voorbeeld, als blijk van bedoelde opvatting, vinden wij m. i. in zekeren lijkzang $\mathrm{rato}^{\leq}$patimah geheeten, die dient om de door een sterfgeval getroffen familieleden te troosten, kapalengahlengah hati nan kamatian, en o. a. dichtregelen telt, zooals de volgende:

Ditjantjang-tjantjang batang hinai. Ditjantjang tjantjang djŏ radawan. Lah tarabang boeroeăng pingai Tarabangnǒ manjisi awan.

De hinaistengel wordt aan stukjes gehakt; Hij wordt aan stukjes gehakt meteen radawan; De vogel pingai is weggevlogen; Hij is weggevlogen langs het hemelgewelf.

Ditjantjang-tjantjang batang hinai. Dibari dimakan hajam $\mathrm{Ma}^{\mathrm{c}}$ tarabangi boeroeăng pingai Tinggalah sangka tampat diam.

Ditjantjang-tjantjang batang hinai. Ditjantjang laloe ka pangkanŏ $\mathrm{Ko}^{\varepsilon}$ pai si boeroeăng pingai Lah tingga tangka karosongno ${ }^{\varepsilon}$

De hinaistengel wordt aan stukjes gekapt; En aan de kippen te eten gegeven; De vogel pingai wilde heen vliegen; Zijn kooi, waarin hij woonde, is achterge[bleven. De hinaistengel wordt aan stukjes gekapt; Hij wordt gekapt tot aan zijn boveneinde; Mocht de vogel pingai zijn heengegaan; Zijn kooi en de afgelegde huid zijn achter[gebleven.

Duidelijk genoeg komt in bovenstaande regelen de voorstelling uit, die men had en soms nog heeft, dat de ziel in de gedaante van een vogel haar omhulsel verlaat.

Dr. Wilken wijst er op, hoe het woord koer of koeroe bij sommige volkeren in den Archipel wordt gebezigd, om de soemangat, alsof zij een vogel of hoen ware, te roepen, hetzij on te voorkomen dat zij wegvliege, hetzij om te maken, dat zij terugkeere, wanneer zij reeds weggevlogen mocht zijn; en zoo ook dat koer soemangatnja! een zeer gewone nitroep bij plotselinge ongesteldheid of schrik is, in welke gevallen de soemangat geacht wordt het lichaam te verlaten 1 . Mocht men voor dit koeroe of

${ }^{1}$ Zie Indische Gids 1884, blz. 948. 
k o er de juiste beteekenis nu niet meer kunnen aangeven, en het vrij algemeen voor een verbastering van koeroes = mager aanzien, iets waartegen evenwel de uitspraak, die dan koeroeih zou zijn, opkomt, - een feit is het, dat dit woord nog bij enkele gelegenheden uit den mond van den Minangkabauer gehoord wordt, o. a. van een moeder, wier kind schrikt, en die daarmede den ontvloden levensgeest van den kleine wil terugroepen. Zoo zegt de Minangkabauer somtijds ook koer of koeroe soemangè̀, indien hij in verachtelijken zin over iets nuttigs of dienstigs spreekt, bevreesd als hij is, dat zijn levensgeest, als straf voor zijn zonde, zal heengaan. Is het gebruik van deze woorden dus niet meer algemeen en kan men zich al geen goede rekenschap geven van hunne beteekenis, uit de aangehaalde voorbeelden mag men toch besluiten, dat, evenals elders in den Archipel, in vroegere tijden ook hier aan de soemangat de gedaante van een vogel werd toegeschreven.

Waar overigens in het menschelijk lichaam de soemangat haren zetel heeft, weet de Minangkabauer niet te zeggen. Vele doekoens houden het er voor, dat dit in het hart is, en voeren als grond van hunne bewering het volgende aan. Wanneer iemand schrikt, legt hij 't eerst de hand op het hari, omdat dit, ten gevolge van het wegvlieden der soemangat begint, te kloppen, darah koemirŏs, zooals de Minangkabauer dat uitdrukt. En verder: al snijdt men iemand armen en beenen af, al wordt hij ook aan het hoofd ten zeerste gewond, hij kan toch in 't leven blijven, maar als hij slechts met een fijne lidi (klappernerf) in 't hart gestoken wordt, moet hij sterven. Ook het zoogenaamde manggajoeăng oerang 1 zou deze meening moeten bevestigen. Dit is namelijk een middel, dat wordt toegepast door iemand, die een ander haat. Terwijl hij voor zijn vijand allerlei onheil, ziekte en zelfs den dood afbidt, geeft hij hem met de hand of met een paar vingers ongemerkt een tik, of raakt hij hem met den voet even aan, zich daarbij voorstellende hem in het hart te treffen. Dit lichaamsdeel toch is voorzien van een tali (koord), dat door de aanraking breken kan, in welk geval de dood spoedig volgt. Breekt het koord niet, dan zijn toch een langdurig lijden, hevige pijnen en tal van tegenspoeden de gevolgen. - Andere doekoens willen dat de soemangat in het geheele lichaam zit. Dit zou ook moeten blijken uit den regel badiri kabatang toeboeah van de hiervoren

\footnotetext{
1 Manggajoeăng = uitvallende beweging bij het schermen maken; stocten, steken naar iemand,
} 
vermelde pantoen, terwijl, te oordeelen naar de overige verzen dierzelfde pantoen, de ringvinger, de duim, de groote toon en de pupil van het oog de deelen zijn, waarin men zich de soemangat in het bijzonder gezeteld denkt.

Als eene bijzondere uiting van het leerstuk omtrent het onafhankelijk bestaan der ziel van het lichaam noemt Dr. Wilken de lykanthropie. De lykanthropos, lezen wij, is iemand die in eenen wolf, of, met uitbreiding van de beteekenis van het woord, in eenig dier zich veranderen kan, juister wiens ziel het vermogen bezit het lichaam tijdelijk te verlaten en in dat van eenen wolf of ander dier over te gaan.

Bij den Minangkabauer van de Padangsche Bovenlanden wordt de lykanthropie niet aangetroffen, en wezens, zooals de $\mathrm{tjindakoe} \mathrm{bij}$ de Koerintjiers, waarvan de Heer Van Hasselt vertelt, zijn hem onbekend. Toch zou men, rekening houdende met enkele sprookjes, die hier en daar nog wel eens de rondte doen, tot de meening komen, dat althans vroeger het geloof moet hebben bestaan aan personen, die het vermogen bezaten, om reeds tijdens hun leven zich in eenig dier te veranderen. Zoo hoorde ik vertellen van een grassnijder, die, naar het bosch gegaan zijnde, niet meer terugkeerde. Zij, die hem gingen zoeken, vonden wel zijn grasmes en korf, maar hij-zelf was spoorloos verdwenen. Een paar dagen later ontmoetten eenige personen "in het bosch een vreemdsoortig wezen, dat deels op een tijger, deels op een mensch geleek. Denkende aan den verdwenen grassnijder, kwam men weldra tot de gedachte, dat het deze kon zijn, die bezig was zich van gedaante te veranderen, en deze gedachte werd overtuiging, toen men, het halfdier gevangen hebbende, dit door kracht van allerlei toovermiddelen weder den menschelijken vorm zag aannemen.

Over het algemeen hecht de Minangkabauer meer aan eene metamorphose, die geheel geleidelijk geschiedt; en behoort hij dus tot de stammen, die de jongere ontwikkelingsphase omtrent dit leerstuk zijn toegedaan. Aangezien de metamorphose voor den Minangkabauer eerst na den dood plats heeft, is eene verdere beschouwing daarvan hier niet op hare plaats en zal daarop teruggekomen worden bij de behandeling van de zielsverhuizing.

Wat het heksengeloof betreft, dat evenzeer een uitvloesel is van het leerstuk van het onafhankelijk bestaan der ziel, Dr. Wilken deelt daarover zooveel mede, dat er hier met een enkel woord over volstaan kan worden. De opvatting van den Minangkabauer is, dat sommige personen de eigenschap is aangeboren, om zieh des nachts het hoofd 
van den romp te scheuren en dit uit spoken te laten gaan, dan wel dit helsche werk met hun geheele lichaam te verrichten.

Van deze heksen, die den naam van palasi $i^{\mathcal{E}}$ hebben, zijn er dus twee soorten: de palasi $i^{\varsigma}$ bangkai en de palasis panangga, of, zooals zij meer algemeen genoemd worden, de palasis koedoeăng 1 en de palasi sabatang badan of sabatangnŏ.

Van de eerste vertelt men, dat, terwijl het hoofd zich van den romp afzondert, de ziel daarin meegaat om rond te spoken, terwijl het afgelegde gedeelte levenloos achterblijft. Tegen den morgen keert het hoofd terug, en de gescheiden deelen vereenigen zich weder tot een levend wezen. De opvatting schijnt dus te zijn, dat de ziel, die zich vrijwillig uit het lichaam kan verwijderen, tevens het vermogen heeft, waar dit eene begeerte of neiging van haar is, bepaaldelijk een enkel deel daarvan zich tot zetel te kiezen en dit van het overige gedeelte af te zonderen. Is men gelukkig genoeg deze heksen op haren rooftocht te overvallen en te bedwelmen, door ze met eenig toovermiddel te bespuwen, waarvan o. a. peper het hoofdbestanddeel is, dan werpt men ze een grooten klapperdop over het hoofd en drukt op dit laatste zoolang met een rijststamper, dat zij van pijn en benauwdheid gedwongen zijn, haren naam te zeggen.

Indien de palasis $\mathrm{sabatang}^{\mathrm{b}} \mathrm{b}$ an uit de woning vertrekt, is hare plaats op de legerstede ledig. Hare komst op de kerkhoven wordt voorafgegaan door die van drie groote koembang tjiri ${ }^{\varsigma}$ - stinktorren - en zij-zelve is vergezeld van drie witte honden. Op de plaats, waar zij een lijk wil rooven, slaat zij met een bundel van zeven klappernerven op den grond, en dwingt zij, door het aanhoudend voortbrengen van een eigenaardig zuigend geluid, gelijk aan dat waarmede men honden roept, den doode het graf te verlaten, waarna zij dezen op eene eenzame plaats verslindt. Gewoonlijk verschijnt zij bij hevige stortregens en stormen.

Te weten, wie palasi ${ }^{\varsigma}$ is, is hoogst moeielijk; kenteekenen echter zijn een paar buitengewoon groote ooren, die ver van het hoofd staan, en een schuine, gluipende blik.

Tot dusverre werd alleen aangetoond, dat door den Minangkabauer

${ }^{1}$ Malasi $\mathrm{i}^{\varsigma}=$ zuigen, opzuigen, uitzuigen; $\mathrm{palasi}^{\varsigma}=$ de persoon, die dit werk verricht; koedoeăng = afgekapt, afgehouwen. De uitdrukking palasis panangga beteekent: de palasi ${ }^{\varsigma}$ aflegger (Boil. vari den romp), palasis.sabatang badan of sabatangno daarentegen: de palasis met zijn geheele lichaam, 
aan menschen het bezit van een soemangat wordt toegeschreven; een paar voorbeelden moge doen blijken, dat ook dieren zulk een levensgeest in zich hebben.

Mampatinggi soemangè andjiĕng mamparandahkan goenoeăng Marapi, d. w. z.: "iets, wat het niet waard is, ophemelen, en wat werkelijk groot of belangrijk is, minachten", is een spreekwoord, dat men den Minangkabauer nog al eens hoort gebruiken, en waaruit blijkt, dat aan den hond een soemangat wordt toegekend, zij het dan ook dat zij als niet veel bijzonders beschouwd wordt. De uitdrukking beteekent toch letterlijk: de soemangat van een hond verheffen, en de Marapi (een bekende berg) verlagen.

Van een buffel of koe, die ter slachtbank wordt geleid, zal men b.v. zeggen: inda $a^{\leq}$basoemang è $e^{\leq}$bantiěng toe la i, dat beest heeft geen soemangat meer, doelende op de stille, droevige uitdrukking in de oogen en op den lusteloozen gang van het dier, wiens soemangat is heengegaan, en waardoor ook aan ons wel eens de uitdrukking ontlokt wordt: ' $t$ is alsof het dier een voorgevoel van zijn dood heeft. Wanneer de meester van een paard gedurende den tijd, dat hij dit in zijn bezit heeft, door veelvuldige ongelukken wordt getroffen, schrijft de Minangkabauer dat toe aan den tegenzin van de soemangat van dat dier: om het eigendom van dien heer te zijn, hetgeen hij eigenaardig uit drukt met de woorden: $\mathrm{k}$ a rèh soemang è $\mathrm{e}^{\mathrm{c}} \mathrm{n}$, zijn soemangat is koppig. 1

Dat de Minangkabauer overigens aan allerlei soorten van dieren het bezit eener ziel toekent, of althans vroeger dit gedaan heeft, is blijkbaar af te leiden uit de omstandigheid, dat er in de Minangkabausche legenden zoo menigvuldig sprake is van dieren, die als menschelijke wezens handelen en gevoelen. Zoo leest men o. a. in den Mandjau Ari 2 van een tijger, die tot een paar zwervelingen zeide: "Hier zal ik mijn eetlust kunnen verzadigen aan menschelijke wezens, die in het bosch verdwaald zijn". Een bladzijde vroeger, wordt iets dergelijks verteld van een bidaislang, en, op een volgende, van een varken. - In den Soetan Manang Kérang ${ }^{3}$ ontmoeten wij een hert, een rhinoceros en een tijger, die spreken kunnen.

1 In dergelijke gevallen hoort men echter meer tinggi rasin vergelijke over dit woord rasi de woordenboeken van v. d. Wall en Pijnappel.

2 Zie Verh. Bat. Gennotschap, Dl. 45, v. d. Toorn.

s Bijdragen tot de T. L. en Vk. van N. I., 4de serie, dl. 10. 
en hulp verschaffen aan den held der legende, dien zij ieder tot aan de grens van hun gebied wegdragen. De vogels $\mathrm{Sik} \grave{o}^{\leq} \mathrm{S}$ a marlaoei redden, na beraadslaging, prinses Andam Déwi uit den buik van een visch, en twee draken voeren haar, nadat zij vooraf twist gehad hadden of zij haar al dan niet zouden opeten, naar de rijstschuur van hunne meesteres Taroeih Matŏ. - In de geschiedenis van Poeteri Balkis 1 spelen vooral twee pauwen (maras ${ }^{5}$ ) een hoofdrol. Die van de prinses was o. a. beleidvol, verstandig en welgemanierd en sprak altijd de waarheid. Eenmaal hoort men hem zelfs tegen de prinses zeggen, dat hij haar met den koning der wereld zal samenbrengen, en "in zijnen geest" haar reeds met den vorst (Soelaiman) vereenigd ziet. Die van Salomo was even verstandig en knap. In ditzelfde verhaal komt ook een kraai voor, die spreken kan, en die door Soelaiman als afgezant wordt gebruikt. Deze vorst zeide o. a. : "Geesten, vogels en andere dieren van het woud en menschen, verzamelt u allen, opdat prinses Balkis kan zien, dat ik haar met luister ontvang ". Alle menschen kwamen daarop bijeen, de dieren verlieten het woud, de vogels kwamen uit de boomen, de geesten kwamen van de eilanden, zoodat de uitgestrekte plaats vol raakte. Daarop beval Soelaiman weer: "Gaat nu allen geregeld staan, mijn onderdanen; vermengt $\mathrm{u}$ niet met elkander: vogels bij vogels, tijgers bij tijgers, slangen bij slangen, kruipend gedierte bij kruipend gedierte, herten bij herten, siamangs bij siamangs, neushoorns bij neushoorns, kippen bij kippen, mieren bij mieren, enz." Nauwelijks hadden zij de woorden van den koning gehoord, of het volk (hiermede worden de onderdanen, dus allen die opgenoemd zijn, bedoeld) ging op weg. - De geschiedenis van Tjindoer Matŏ 2 brengt den lezer in kennis met een stier, Binoeang geheeten, die begon te schreien, toen de vorstin, zijne meesteres, afscheid van hem nam, terwijl de legende van Moerai Batoe ${ }^{3}$ eveneens een vogel sprekende en handelende opvoert.

Mocht verder, wat het bezield-zijn van levenlooze voorwerpen aangaat, de Minangkabauer tegenwoordig meer de voorstelling toegedaan zijn, dat daarin de ziel huist van een geest, hetzij van een goeden of van een kwaden - een leerstuk dat dus eigenlijk bij

1 Zie Verh. Bat. Genootschap, Dl. 4l, Gerth v. Wijk.

2 Verh. Bat. Genootschap, Dl. 45, v. d. Toorn.

s Van Hasselt, Volksbeschrijving van Midden-Sumatra. 
het fetisisme of spiritisme tehuis hoort - afgaande op hetgeen vooral van sommige natuurobjecten wordt verteld, zou men kunnen aannemen, dat het geloof aan eene wezenlijke bezieling daarvan vroeger wel moet bestaan hebben. Dit moge straks blijken.

Wat de gewassen betreft, is het de rijst waaraan de Minangkabauer thans nog bepaaldelijk een soemangat toekent. Dit blijkt onder anderen uit de meening, die men wel eens hoort verkondigen, dat de rijst op de gewone wijze gestampt, lekkerder is dan die uit de pelmolens, daar bij deze laatste, ten gevolge van de ruwe behandeling, de soemangat uit de korrels gevloden is. Doch vooral hebben wij de aandacht te vestigen op de beschouwingen en gebruiken omtrent de zoogenaamde in d o e ă ${ }^{s} \mathrm{padi}$.

Evenals de Javaan, gelooft de Minangkabauer, dat de rijst onder de bijzondere bescherming staat van een vrouwelijken geest, Saning Sari geheeten ${ }^{1}$, die hij zich met het gewas zoodanig vereenzelvigd denkt, dat hij dit laatste dikwijls naar haar heet. In het bijzonder wordt echter Saning Sari vertegenwoordigd door enkele halmen of korrels, indoeă ${ }^{\varsigma}$ padi, dat is letterlijk: moeder van de rijst, eene benaming die dikwijls ook aan den beschermgeest-zelven gegeven wordt. In het bestaan van deze indoeă padi vindt men den grond voor een aantal ceremoniën bij het planten, oogsten en bewaren van de rijst in acht genomen, waarvan wij er enkele in 't kort willen aangeven.

Den dag voordat men op de kweekbedding de banih $=$ de zaadpadi gaat uitstrooien, worden de daarvoor bestemde korrels in het late avonduur, als alles stil en rustig is, afgemeten, waarbij het een verbod is de soekat of maat af te strijken. Dit geschiedt onder het opzeggen van de doa: Bismillah moedjoeă satangkai

1 Volgens Dr. Wilken zou de naam Saning Sari beantwoorden aan Sangijang Çri. Intusschen -moet opgemerkt worden, dat die naam dikwijls anders wordt opgegeven. Zoo hoort men, naar men mij bericht, meermalen, respectievelijk in Soengai Pagoe en in Oud-Agam, Si nan Sari en Sinang Sari. Aan sari nu geeft de Minangkabauer de beteekenis, welke men er ook, nevens die van Ceres, in de woordenboeken voor vindt, namelijk: de quintessens, de voedende bestanddeelen, de proteine. De naam Si nan Sari zou dan beteekenen: de bij uitstek voedende. Wat Sinang Sari betreft, daarin zou sinsng eene samentrekking zijn van si en inang = verzorgster, zoodat de naam zou zijn te vertalen door: de verzorgster van sari, van de voedende bestanddeelen. Elders hoort men spreken van Sana, Sanan, Sanang, Saling, Silang, Sadiěng Sari, enz., en tracht men, onder allerlei gezochte verklaringen, zijne onkunde omtrent de beteekenis van deze namen te verbergen. 
sasoekès, saroempoen sakatidiĕng; kadimakan anas boeah; kadimakan oerang samandŏ; kaparara ${ }^{\varsigma}$ kapaririĕng kapadjamoe goeloĕang lapiĕ ${ }^{\varsigma}$, d. w. z.: "In den naam van God, moge ik gezegend worden, zoodat een halm een soekat, een stoel een mandvol moge opleveren, tot voedsel voor mijne kinderen en familieleden, tot onthaal van ons, wanneer wij in feestdos rondgaan, en tot onthaal van de volgelingen daarbij, en om te dienen daar, waar men slechts één dag gasten heeft". De padi wordt dan op een matje in verschillende hoopjes, soort bij soort, gelegd en, onder het opzeggen van een doa, met water besprenkeld, waarin o. a. bladeren van den si tawar en si dingin gelegd zijn, en uit deze hoeveelheid korrels worden weer de beste uitgezocht, om op de kweekbedding tot in $\mathrm{doe}^{5} \mathrm{p}$ a di te dienen. Den volgenden morgen plant men, voor het uitzaaien, in het midden der kweekbedding, nog van dergelijke planten, die den naam dragen van djoendjoeăng banih 1, zijnde zij het, die de indoeă ${ }^{\varsigma}$ padi tot een geheimzinnigen steun verstrekken. De opvatting toch is, dat de toestand van de indoeă $^{\varsigma}$ van den meesten invloed op het gewas is, en een slechte oogst er het gevolg van moet zijn, als zij ziek wordt of kwijnt. Om deze djoendjoeăng plant meu de indoeă ${ }^{\varsigma}$ padi en daaromheen de gewone zaadpadi. Op weg naar de kweekbedding gaande, werpt men; op het erf voor de woning, een handvol van het laatste uit voor de kippen, daarbij roepende: koeroe ajam! sabanja padi ajam mantjotós, sabanjas padi dèn! hetgeen beteekent: "moge mijn padi even menigvuldig worden, als de kippen oppikken!" De vrouwen, die dit doen, hebben de haren loshangen en gaan zich, na afloop daarvan, met limau-water reinigen eu baden, alles als zinnebeeld van een overvloedigen oogst en uit eerbied voor de indoeă ${ }^{\varsigma}$ padi.

Is de tijd daar, dat de banih kan worden overgeplant, dan bespuwt men de indoeă ${ }^{\varsigma}$ padi met sirih en pinang toeǒ of begiet men haar met rijstewater, waarna haar gewoonlijk in een hoek of in het midden van het veld een plaats wordt aangewezen. De doa, waarmede dit gepaard gaat, luidt o. a.: Saning sari satangkai sa soekès, saroempoen sakatidiĕng; djan takadjoeis digoeroeăh dan di patoeih, djan takadjoeis di oerang laloe; kò panēh baó gala k kò riboei ${ }^{\varsigma}$ rilahkan, kò hoedjan pambasoeă moek ŏ! d. w. z.: "Saning Sari, moge van een rijsthalm een soekat, van een stoel een mandvol komen; moogt ge

${ }^{1}$ djoendjoę̊ng = staak, latwerk, waartegen klimplanten opgroeien. 
niet bevreesd gemaakt worden, noch door den bliksem, noch door voorbijgangers! Zonneschijn make u blijmoedig, met den storm moogt ge vrede hebben, en regen zij u het middel, om het gelaat te wasschen!" Terwijl de rijst groeit, wordt deze indoeà ${ }^{s}$ padi uit het oog verloren ; doch vóór de oogst van het veld gehaald is, heeft men een andere gevonden. De algemeen heerschende meening toch is, dat zij als beschermengel of schutsgeest ook in de loemboeăng of rijstschuur voor het product zorg draagt en dit niet zelden ook daarin doet vermenigvuldigen. Als de padi nu zoo rijp is, dat zij gesneden kan worden, gaat het oudste vrouwelijke familielid of eeu doekoen naar het veld, om de nieuwe indoeă ${ }^{s}$ padi te zoeken, of, zooals men elders zegt, om te mandjapoei ${ }^{5}$ padi toedjoeăh samandŏ, d. i.: om de zeven zusterhalmen af te halen. Onder het prevelen van een doa, wordt het gewas met limau-water besproeid en de planten, die zich dan het eerst buigen - volgens het geloof van den Minangkabauer natuurlijk uit zichzelve - bevatten de indoeă padi, waarnaar gezocht wordt. Met een paar stengels, opzettelijk daarvoor meegebracht, worden nu de gevonden padihalmen bij elkander gebonden, doch deze niet afgesneden, vóórdat men de zoogenaamde oeloe tahoen huiswaarts heeft vervoerd. Deze is de eerste vrucht van het veld, dienende tot een feestmaaltijd voor familieleden en goede kennissen en tevens voor de huisdieren, daar de beschermgeest wil, dat men ook dezen van hare goede gaven zal doen nuttigen. Na afloop daarvan, wordt de indoeăs padi afgehaald door eenige fraai nitgedoste lieden, die haar zeer zorgvuldig, onder een scherm, in een sierlijk gewerkt zakje of taschje $\mathrm{kamboe} \mathrm{i}^{\text {s }}$ - naar de loemboeăng overbrengen, waar zij haar een plaatsje in het midden geven. Een en ander geschiedt in alle stilte, terwijl het opbergen van de indoeăs padi met meerdere ceremoniën gepaard gaat, onder anderen met het branden van een wierookoffer.

Hiermede zijn de plechtigheden en formaliteiten tegenover de indoeă padi of Saning Sari niet ten einde. Is toch de oogst afgeloopen, dan wordt er, alvorens dat met het trappen, dat is het dorschen, van de padi een begin wordt gemaakt, aan den voet van de lampoeăs $=$ padihoop, een schaal gekookte rijst neergezet als voedsel voor Saning Sari. Zoo ook besprenkelt men, wanneer de rijst voor den eersten maaltijd bestemd, onder het te drogen liggen, gekeerd wordt, de palen, waarop de loemboeăng gebouwd is, met water, waarin lagoendien limau-manih-bladeren gedaan zijn, en legt men op het rijstblok, 5e Volgx. V. 
waarin zij gestampt wordt, een stuk lijnwaad. Die eerste rijst mag, op de droogmat liggende, niet verlaten worden, ook niet als geschenk dienen, en moet zonder spreken worden genuttigd. Vóór den zevenden dag mag men haar ook niet uit de rijstschuur halen.

In verband met de opvatting van de rijst als een bezield wezen, bestaan bij den Minangkabauer eene menigte pantangan's. Het woord pantang beteekent: ongeoorloofd, verboden, met het oog op de nadeelige gevolgen, die uit het doen van iets voortvloeien. Ongeoorloofde handelingen tegenover de rijst zijn o. a.:

Op het rijstveld zijn baadje uittrekken om daarmede het hoofd te bedekken; - de padikorrels vallen er door uit de halmen;

het lijk van eene in zwangerschap gestorven vrouw voorbij de padi te dragen; - de halmen rollen zich dan op en willen geen bloesems voortbrengen;

natte kleeren te drogen hangen aan den keukenzolder; - de rijstkorrel wil dan bij het koken niet zwellen;

terwijl de vrouw onrein is (de menstruatie heeft) in de nabijheid van de padi komen; -- de rijstkorrels bederven er door;

met ongedekt hoofd, boven- of onderlichaam op het rijstveld of in de loemboeăng zijn ; - dit is een groote beleediging Saning Sari aangedaan, waarvan het gevolg is, dat de hoeveelheid padi vermindert;

de padi anders, dan door ze te dragen, naar huis brengen; - zij wil, door deze oneerbiedigheid vertoornd, niet in de rijstschuur blijven;

onkuische taal op het rịstveld spreken; - de rijst schaamt zich daarover en verliest haar soemangès, d. w. z. zij wordt ziek of verliest kleur en smaak;

de rijst, die men van 't veld gehald heeft, onder het huis opbergen; - de smaak en het voedzame (sarinŏ) gaan er door verloren.

Over het algemeen heeft dus hij, die moebazir 1 tegenover het gewas is, een verdwijnen van zijn oogst of eene vermindering van de kwaliteit der vruchten te wachten. Zooals sommigen zeggen, heeft het ontvluchten uit de loemboeăng plats in den vorm van bijenzwermen, en geschiedt dit onder aanvoering van Saning Sari.

1 In het Riouwsch beteekent moebazir: verkwisting, hier echter: met minachting of op vernederende wijze behandelen. 
Hierboven werd gesproken van de meening bij den Minangkabauer, dat de rijst, onder den invloed van hare indoe ${ }^{c}$, zich zelfs in haar bergplaats nog kan vermenigvuldigen, In verband met dit begrip staat een ceremonie, die nog in enkele streken wordt gevolgd bij den bouw van een padischuur. Als men hiermede n. I. gereed is, wordt er een feestmaal aangericht, waaraan stecds en hoogst zwangere vrouw moet deelnemen. Op deze zinnebeeldige wijze wordt de wensch geuit, dat de padi zich in een talrijk kroost verheugen moge.

Treft men dus bij den Minangkabauer al geen cehtpar an dat, evenals bij den Javaan, aan linggam en yoni offert om daardoor de teeldrift bij de rijst op te wekken, in het bovenbeschrevene kan men toch grond genoeg vinden om te onderstellen, dat de bevruehting, zooals die bij den mensch geschiedt, ecumaal ook wan de rijst werd angenomen, en dat deze beschouwing ten decle nog bestast. Dit is verder af te leiden uit den naam andai gadih, d. i. letterlijk: maagdelijke moeder, dus: vrouw, die geen kinderen heeft ter wereld gebracht, zooals in sommige streken het gewas in het algemeen, in tegenoverstelling van de indoeă ${ }^{\varsigma}$ padi, genoemd wordt. Dat de padi-korrels beschouwd worden, kinderen te zijn ran de indoeăs, blijkt verder uit de gewoonte, die men hier en daar nog aantreft, om, na het uitzaaien van de banih op de kweekbedding, boe bo eă = rijstepap te eten, als zinnebeeld van de goede voeding, die men hoopt, dat door de indoeă ${ }^{\varsigma}$ aan haar telgen zal gegeven worden.

Wat hierboven verteld is, betreft in hoofdzaak het landschap OudAgam. De ceremoniën elders komen echter vrij wel op hetzelfde neer. In Natal b. v. wordt de indoeăs padi opgespoord door een doekoen, die, onder het opzeggen van een doa, zeven malen met een doek over de rijst wuift, om te zien welke halmen zich het eerst bewegen. Van deze neemt hij zeven halmen, die met ban a ng pa ntja ro en ŏ, d. w. z. een draad van drieërlei kleur, omwonden en, na bewierookt te zijn, aan den hoofdstijl van de woning vastgebonden worden. In Soengai Pagoe wordt de indoeă $\breve{c}^{\varsigma}$ padi aan een boomwortel en een bamboe vastgehecht, welk werk men maoetjapi= roepen, uitnoodigen noemt. Gedurende de drie eerste dagen nadat zij is tehuis gebracht, mag de eigenaar van het rijstveld geen geld uitgeven en moet hịj, gebrek hebbende aan iets, dit bij een ander leenen. Overtreding hiervan heeft den toorn van Saning Sari ten gevolge. In andere streken weer zoekt men zeven padi-stoelen, en wordt voor de indoeă ${ }^{\varsigma}$ uit elk daarvan een halm afgezonderd. Vandaar de naam van 
toedjoeăh samand̆ (in 't algemeen is sa mand̆ = aanverwant, bloedverwant), die in verschillende negorijen voor de rijst voorkomt $'$.

Het behoeft zeker wel niet gezegd te worden, dat, onder den invloed van den Tslam, tal van oude geloofsbegrippen verloren gegaan zijn, en vele, die bleven voortleven, gewijzigd en met den nieuwen godsdienst zooveel mogelijk in overeenstemming zijn gebracht. Daaraan mag het toegeschreven worden, dat men b. v. aan de benaming van indoeă ${ }^{\varsigma}$ padi thans dikwijls alleen de beteekenis van hoofdplant in het rijstveld wil gegeven zien, niettegenstaande men boven beschreven ceremoniën tegenover haar in acht blijft nemen. Zoo ook wordt de doa niet altijd meer beschouwd als gericht tot den schutsgeest der rijst, maar ziet men daarin slechts een bede, waarmede men om zegen van den alvermogenden Allah vraagt.

Mocht er bij de andere planten van een soemangat geen sprake wezen, enkele begrippen, die men in de legenden aantreft, en de gebruiken tegenover sommige gewassen ook thans nog wel eens in acht genomen, zouden tot de veronderstelling moeten brengen, dat er bij den Minangkabauer ook min of meer aan een bezield-zijn van dezen geloofd wordt. Zoo leest men b. v. in den Tjindoer Matǒ, dat, toen de Toeankoe op reis ging, de planten zich eerbiedig voor hem bogen, a la h soedoed tanam tin a man. Zoo bestaat sporadisch de gewoonte, om, bij het planten van klappers en pisang, een jong kind op den schouder mee te dragen, en heerscht elders het begrip, dat het zaaien van peper of djagoeng niet moet overgelaten worden aan lieden, die hun gebit kwijt zijn, daar men dan weinig of geen vruchten te verwachten heeft.

Wij zijn nu gekomen tot de vraag, hoe de animistische beschouwing van den Minangkabauer is ten opzichte van het voortbestaan der ziel na den dood.

1 Naast de indoeă 5 adi, kent de Minangkabauer ook o. a. nog een indoeăs amè $(a)$ en een indósac katoemboeăhan $(b)$. De eerste heeft een zeer geheimzinnige afkomst, en wordt door sommigen zelfs beschouwd als uit den hemel te zijn gevallen. Hij, die haar vindt, is verzekerd van een onuitputtelijken rijkdom, daar deze indoea steeds voor het aanwezig zijn van meer goud zorg draagt. Spilzucht of vorkwisting echter zijn oorzaak, dat zij op even geheimzinnige wijze verdwijnt. Men ziet het, 't moebazir treedt ook hier weer op den voorgrond. Evenzoo is or onder de pokken, die het lichaam bedekken, er eene, die gezegd wordt de moeder te zijn, uit wie de anderen zijn voortgekomen.

(a) $\mathrm{am} \dot{\mathrm{m}} \mathrm{h}=\mathrm{emas}=$ goud.

(b) katoemboeăhan = pokgiekte. 
Gelijk boven is aangetoond, acht de Minangkabauer zich in het bezit van twee zielen, de eene nja ŏ réhan of soemangés, de andere nja ŏ $n$ an sabananŏ of eenvoudig $n j$ a ŏ geheeten. Deze laatste wordt, waar het de ziel van een afgestorvene geldt, meermalen met het Arabische a roeăh aangeduid, zij het dan ook dat meu voor hilang soemangè wel eens hilang a roeăh hoort gebruiken.

Terwijl, zooals wij zagen, de soemangat verdwenen is op het oogenblik dat het lichaam krank begint te worden, neemt de njaǒ eerst afscheid bij den dood. De engel Gabriël stijgt met haar naar het hemelruim en laat haar daar de plaats aanschouwen, die zij er in de eeuwigheid zal erlangen. Daarna voert hij haar terug naar de aarde, waar hij haar nederzet aan het hoofdeinde der stervenssponde. De doode heeft nog het vermogen om alles te hooren, wat er gesproken wordt; alles te zien, wat er om hem heen gebeurt; alles te gevoelen wat men hem aandoet. Alleen de spraak ontbreekt hem. Op weg naar het graf wordt de draagbaar nog eenige stonden nedergezet op het voorplein van de .woning, om de ziel gelegenheid te geven vergiffenis te vragen voor al het kwaad den haren aangedaan en afscheid te nemen van al wat haar lief geweest is. Tingga sahabat, handai dan tolan, fluistert zij, tingga kampoeăng, tingga halaman, tingga tapian tampè mandi, d. i.: "vaartwel vrienden en kameraden, vaartwel mijn dorp en erf mijner woning, vaarwel mijn badplaats". Naar men mij mededeelde, bestaat in het Soloksche het begrip, dat de ziel aan de haren verzoekt er in te berusten, dat zij moet heengaan naar 't zielenoord, de kampoeang achirat, zooals de Minangkabauer dat eigenaardig uitdrukt. Verder vergezelt de ziel het lijk niet, doch keert zij naar de ouderlijke woning terug, waar zij zich op den zolder of op den nokbalk plaatst. Die van den man bezoekt dagelijks de woning der weduwe; van eene vrouw echter blijft de ziel voortdurend bij de ouders, tenzij die vrouw tijdens haar leven eene afzonderlijke woning gehad heeft, in welk geval de ziel ook daar van tijd tot tijd heengaat. Dit duurt zoo honderd dagen, na verloop van welken tijd de ziel zich zetelt op de medjan, d. z. de twee steenen, die op het graf van den overledene zijn geplaatst, wachtende daar op den dag des oordeels. Alleen één keer in de week, n.l. op Donderdagavond, komt zị eenige stonden toeven in haar vorig verblijf. Het is dan ook daarom, dat men dien avoud veelal in gebed doorbrengt en zich wacht voor huiselijke oneenigheden. Panggang ba'a koemajan, mandoa ba'a sakètès, sanang-sanang samiěng ba'a, aroeăh kan habih poelang kini kŏ, zeggen 
de huisgenooten tot elkander, hetgeen beteekent: "laten wij een reukoffer branden en een weinig bidden; laten wij tevreden onder elkander zijn, want de ziel van onzen afgestorvene zal zoo dadelijk tehuis komen". Gedurende die honderd dagen worden de zit- en ligplaats van den doode zindelijk en schoon gehouden, want diens ziel ergeren, door daarin nalatig te zijn, mag men niet. Met eerbied en erkentelijkheid wordt over den gestorvene gesproken: zijn ziel toch heeft het vermogen hulp te verleenen, en menigmaal wordt deze in moeielijke omstandigheden ingeroepen. Gedragen de nagelatenen zich oneerbiedig, dan verlaat de ziel reeds vóór den honderdsten dag hare woonplaats, om die dan te kiezen in het huis van vredelievende bloedverwanten. Nim'ner keert zij dan tot de haren weder; hulp verschaffen wil zij hun niet meer, en niet zelden wreekt zị zich over de onheusche bejegening haar aangedaan.

$\mathrm{Na}$ den 100sten dag verlaat de ziel deze aarde en gaat naar het zielenland, de kampoeng achirat of nagari kakal, in het luchtruim, d.i., naar de door den Islam gewijzigde voorstelling, voor velen thans de siroeğo, de hemel, het verblijf der_braven, of de $\mathrm{n}$ arak ŏ, de hel, de plaats der boosdoeners.

Welke voorstelling men zich vormt omtrent dit heengaan van de ziel naar de kampoeng achirat of nagari kakal, blijkt o. a. nog nit de volgende verzen van de boven genoende Ratǒ ${ }^{5}$ Patimah:

Ditjantjang-tjantjang batang hinai De hinaistengel wordt aan stukjes gehakt;

Ditjantjang laloe ka hoeratnjŏ Lah tarabang boeroeăng pingai

Tarabang djŏ soerès-soerè ${ }^{\varsigma}$ nŏ

Ditjantjang-tjantjang batang hinai Boengŏnjŏ diambiě ka oebat I tah pai si boeroeăng pingai Pai dibaŏ malaikat.

Ditjantjang-tjantjang batang hinai De hinaistengel wordt aan stukjes gekapt: Boeahnjǒ dimakan djawi Mamboeboeăng si boeroeăng pingai Dirintang ana $\mathrm{a}^{\mathrm{s}}$ bidadari.

Ditjantjang-tjantjang batang hinai Diambiĕ ka oempan poejoe Tah rahi $^{\varsigma}$ si boeroeăng pingai Di sisi awan nan koelaboe.
Hij wordt gehakt tot aan den wortel;

De vogel pingai is weggevlogen; Hij is weggevlogen met zijn lotsbeschikking 1

De hinaistengsl wordt aan stukjes gekapt; Zijn bloemen worden genomen tot geneesmiddel; De vogel pingai is heengevlogen; Weggebracht door den doodsengel.

Zijn vruchten worden door de koeien gegeten; De vogel pingai is opgestegen; De luchtgeesten zijn daardoor in groote drukte.

De hinaistengel wordt aan stukjes gehakt; En tot lokaas gebruikt voor de poejoe; De vogel pingai is verdwenen; Langs het blauwe hemelgewelf.

\footnotetext{
1 In dieu zin komt het woord soerat meer voor.
} 
Een andere meening omtrent het zielenland hoort men wel eens door sommige ingewijden, vooral door doekoens, verkondigen. Deze zeggen namelijk, dat de ziel, na verloop van honderd dagen, ergens het wereldruim inspoedt en zich daar verder ophoudt op de bergen, in de bosschen, op groote boomen, in steenen en bronnen. Daar ontmoet zij de zielen van vroeger gestorvenen en leidt er hetzelfde leven als op aarde. Met de ziel van hen, die in den oorlog gebleven of in het water omgekomen zijn, geschiedt dit eveneens. Genoemde plaatsen en voorwerpen staan dan ook nog zelfs bij hen, die den Islam omhelsden, in een reuk van heiligheid, en niet zelden wordt er den geesten der afgestorvenen een offer gebracht. Uit een en ander kan dus genoegzaam blijken, dat bij den Minangkabauer de opvatting bestaan heeft en - al is hij er zich minder van bewust nog bestaat, dat het hiernamaals of het zielenland op de aarde-zelve is gelegen. De bezoeken, die de zielen ook nog wel na den houderdsten dag, gewoonlijk op Donderdag avond of op feestdagen, bij de haren afleggen, getuigen evenzeer voor deze meening.

Het tijdstip, waarop de ziel geacht wordt, naar haar eeuwige woonplaats heen te gaan, is - we zagen het reeds - na den honderdsten dag. Hiermede is meer dan waarschijnlijk het feit in verband te brengen, dat het doodenfeest, op dien dag gevierd, het grootst is, en dat men dan in optocht de laatste rustplaats nog eens opzoekt. Waar de achtergeblevenen weten, dat de ziel thans voorgoed afscheid neemt, moet, vóór de lange reis naar het nieuwe vaderland door haar aanvaard wordt, haar nog eens in ruime mate een blijk gegeven worden van eerbied en toegenegenheid. Een uitvloeisel daarvan mogen we ook zien in het zoogenaamde mandjapoei ${ }^{\varsigma}$ dansana $a^{s}$ mandjalang soedah 1, dat door den Heer Van Hasselt wordt beschreven, en bestaat in een afscheidsbezoek van de weduwe aan de familie van haren echtgenoot, met welke familie zij dan ook een bedevaart naar zijn graf doet.

In het voorgaande vindt men blijkbaar ook de verklaring van het gebruik om de boedelscheiding, bij overlijden van de vrouw, eerst na den honderdsten dag, bij overlijden van den man echter, reeds den dag na de begrafenis te doen plaats hebben. Zooals wij toch gezien hebben, blijft van eene vrouw de ziel voortdurend in de familiewoning, daar dus waar die vrouw, tijdens haar leven,

\footnotetext{
${ }^{1}$ mandjapoeis dansanas $a^{s}=$ de bloedverwanten afhalen. mandjalang soedah = een eindbezoek afleggen.
} 
met haren man heeft samengewoond ${ }^{1}$. Gedurende dien tijd wordt de weduwnaar nog als medebewoner van dat huis beschouwd, en is de huwelijksband feitelijk dus niet geheel verbroken. De ziel van de vrouw wordt derhalve geacht met den man nog alle goederen in gemeenschappelijk gebruik te hebben, totdat zij voorgoed afscheid neemt om naar het zielenland te vertrekken, dat is tot den honderdsten dag, op welk tijdstip dan ook de boedelscheiding plats heeft, de weduwnaar het zijne bekomt en weggaat. Is echter de man gestorven, dan verlaat diens ziel reeds terstond na de begrafenis het huis der vrouw, om in de eigen familiewoning haren intrek te nemen. De echtverbintenis is dus feitelijk dadelijk verbroken, en van een verder gemeenschappelijk gebruik der goederen kan geen sprake meer zijn. Het is dus noodig, dat ieder terstond het zijne krijgt, en vandaar dat men in dit geval reeds zoo spoedig tot de boedelscheiding overgaat.

Gaan wij nu na welke de opvattingen zijn omtrent het leerstuk der zielsverhuizing of wedergeboorte, dat ook bij den Minangkabauer wordt aangetroffen.

Zoodra de personen, die het lijk grafwaarts hebben gedragen, slechts op een afstand van zeven schreden van de groeve verwijderd zijn, beginnen voor den doode, zoo hij een boos doener is geweest, de straffen der eeuwigheid. Deze veroorzaken hem zulk een lijden, dat hij de hulp inroept van den engel Gabriël, wien hij smeekt bij Allah zijn voorspraak te willen zijn, om op aarde als mensch te mogen wederkeeren, ten einde, door het verrichten van goede en vrome werken, de vroegere zonden uit te wisschen. Allah's besluit is echter eene weigering, en de doode vraagt nogmaals, om dan toch als dier te mogen herleven. Vó́r of op den zevenden dag wordt deze bede toegestaan: de doode verrijst van uit zijn donkere rustplaats, en de ziel komt in het lichaam terug. Het hoofd heeft echter den vorm aangenomen van dat eens diers, gewoonlijk van een tijger, boschzwijn of slang. Dit wezen, hetwelk den naam draagt van oerang djadi-djadian, zet zich neder in de nabijheid van de woning zijner familie, waar het eenig voedsel ontvangt, doch ook tevens verzocht wordt, zich te verwijderen. Badjalanlah dahoeloe, zegt men, kahabih takadjoei ${ }^{\text {s }}$ padja-padja oerang laloe bagai,d.i. : "ga weg, als 't u belieft, de kinderen en ook de voorbijgangers zullen bang worden". Het

${ }^{1}$ Gelijk van algemeene bekendheid is, blijft, als een uitvloeisel van de instelling van het matriarchas, bij de Minangkabauers, de vrouw bij het huwelijk in hare familiewoning, terwijl de man daar zijn intrek neemt. 
halfdier gehoorzaamt, maar verwijdert zich toch niet ver van de woning. Wanneer er nu wederom zeven dagen zijn verloopen, is het vreemdsoortig wezen geheel in een dier, hetzij tijger, aap, varken, enz., veranderd, en heeft het op het leven der zijnen eenen grooten invloed. Het staat hen bij in gevaren, helpt hen in moeielijke omstandigheden, en vergezelt hen op verre reizen. Doodt men het, dan keert het toch weer in het leven terug.

Zooals dus blijkt, hecht de Minangkabauer thans minder aan eene zielsverhuizing, dan wel aan eene wedergeboorte als dier, en heeft deze, misschien als eene latere wijziging, min of meer het karakter van straf, aangezien het bepaaldelijk boosdoeners zijn, die dit lot ondergaan. De metamorphose heeft geleidelijk plaats; want, zoo vertelt men, het wezen wordt in het eerste stadium der vormverandering wel eens ontmoet, heeft dan den kop van een tijger, slang of varken, en een lichaam, dat met dunne haren is begroeid, en dat dikwijls nog gehuld is in het doodsgewaad. Van den tijger, die vroeger mensch was, zijn de tanden afgevijld; hij onderscheidt zich door een sterk begripsvermogen en een voorkomen, dat vrees en ontzag inboezemt. In het graf vindt men eene opening, en de plaats, waar de doode gerust heeft, is ledig.

Volgens sommigen zou de wedergeboorte van mensch in dier, en van dit dier in een ander, zeven malen geschieden, en daarna van het eenmaal als mensch bestaande niets meer overblijven dan aarde. Volgens anderen heeft de metamorphose slechts eenmaal plaats, en gaat de ziel, nadat het dier gestorven is, naar het zielenland 1. Opmerking verdient het nog, dat, volgens sommigen, de metamorphose erfelijk is in een familie, hetzij voor alle leden er van, hetzij slechts voor enkele ${ }^{2}$.

1 Een uitvloeisel van het begrip, dat eenig dier uit een ander kan voortkomen, is b. v. het verbod, hier en daar bestaande, om de kat bij haren naam te noemen, wijl men gelooft, dat zij uit een koningstijger ontstaan is. Zoo willen sommigen ook, dat de zoogenaamde sipoeloeis bega, een kleefrijst, onder het groeien in gewone padi veranderen kan, terwijl anderen weer vertellen dat de oebi, te groot wordende, een draak kan worden.

2 Personen, die zich, door middel van tooverformules, bij de wedergeboorte in een der door hen gewenschten toestand kunnen verplaatsen, worden bij den Minangkabauer niet aangetroffen, en evenzoo is de kluizenaar bij hem een geheel ander persoon, dan bij den Javaan. De Minangkabauer toch begeeft zich in afzondering, alleen met het doel om in aanraking te komen met geesten, van wie hij de eene of andere tooverij wil leeren, zooals b. v. die om zich onkwetsbaar te maken. Gewoonlijk gaat hij daarvoor naar den top van een hoogen berg of in het dichtste gedeelte van het woud, wasr hij blijft totdat hij zijn wensch vervuld ziet, meestal echter niet langer dan zeven dagen. 
Wat de herinnering aan den vorigen levenstoestand betreft, deze blijft voor den Minangkabauer bij de wedergeboorte bestaan. Het dier geworden mensch toch weet het huis zijner bloedverwanten terug te vinden, herkent de personen, die vroeger de meeste toegenegenheid voor hem koesterden, en gevoelt zich tot enkelen hunner bij voorkeur aangetrokken, zoodat hij hen op verre reizen vergezelt en, waar het noodig is, op den rug neemt. Op aarde teruggekeerd, tot straf voor zijn zonden, heeft het berouw daarover en toont dit, door zijn beschermeling, wanneer het met dezen in de eenzaamheid is, van een of ander kwaad terug te houden 1.

Een natuurlijk uitvloeisel van het leerstuk der zielsverhuizing of wedergeboorte is het geloof aan de verwantschap van menschen met dieren, bepaaldelijk met die, waarin men zich de afgestorvenen bij voorkeur geincarneerd denkt. Deze dieren worden met eerbied behandeld. Dit blijkt uit de bijzondere namen aan hen gegeven, met het doel hen daardoor te streelen of hunne booze gezindheid te matigen. Zoo heet b. v. de tijger inji ӗ gevlekte voor- of grootvader, het boschzwijn inji ĕs tjentjeng ${ }^{2}$, de muis injiës poeti ${ }^{3}$. Het zal dan ook bij den Minangkabauer niet opkomen van een tijger kwaad te spreken, of hem op andere wijze onaangenaam te stemmen; hij durft hem menigmaal niet eens bij den naam van harimau of rimaute noemen, doch spreekt gewoonlijk van toean, d. i.: heer. Alleen op bevel zal men hem dooden, of wanneer het gevreesde wezen in de kampoeng onheil heeft berokkend, terwijl men dan nog eerst trachten zal, het levend te vangen, ten einde in de gelegenheid te zijn het vergiffenis te vragen voor het feit, dat men het zal ter dood brengen. Er mocht in den omtrek een der verwanten aanwezig zijn, die anders de euveldaad zou wreken. Het varken en de muis worden inji ě ${ }^{\varsigma}$ genoemd in de overtuiging, dat deze dieren ten gevolge dezer vleierij de op het veld staande vruchten meer ontzien zullen. Waar men hen verjagen of dooden wil, roept men de hulp in van een geest, onder belofte van een offer, zoodra de oogst zonder veel schade is binnengebracht.

\footnotetext{
1 Als eene bijzonderheid stip ik hier nog aan, dat de tijger iemand altijd van achteren aanvalt, omdat hij volgens den Minangkabauer vrees gevoelt voor de spreuk: "God is groot", die op het voorhoofdsbeen van den mensch staat geschreven. Ook de palasi ${ }^{\varsigma}$ durft daarom niemand aan te kijken.

${ }^{2}$ tjentjeng = lief, anvallig,

${ }^{3}$ poeti $=$ prinses.
} 
Behalve aan de zooeven genoemde dieren, wordt door den Minangkabauer aan den krokodil veel eerbied bewezen, dewijl, zooals de legende zegt, zijn groote wetgever Katoemanggoengan als zoodanig is herboren. De nakomelingen van dezen Katoemanggoengan, waartoe, naar men mij mededeelde, de Regent van Indrapoera en zijne familie gerekend worden te behooren, zijn dus aan de krokodillen verwant, en erlangen dan ook, als zij b. v. op reis gaan, in menig opzicht hulp en bescherming van deze dieren. Een voorbeeld van krokodillenvereering vindt men overigens in de ceremoniën, die o. a. op enkele strandplaatsen plaats hebben, als zulk een dier gevangen is. Een menigte vrouwen voeren dan verschillende dansen uit, veel overeenkomst hebbende met die, wanneer iemand gestorven is. Hetzelfde gebeurt, om dit hier nog op te merken, in sommige streken, alvorens dat een gevangen tijger van het leven wordt beroofd.

Bij Kapau, een plaats in de nabijheid van Fort de Kock, is een vijver vol heilige visschen, die, volgens sommigen, gezegd worden van een kind af te stammen, dat door zijne moeder aan den kant van het water achtergelaten zijnde, daarin viel en in een visch veranderde. Niemand eet van die visschen, en bij eene pokkenepidemie worden ook zij, volgens het volksgeloof, door die ziekte aangetast 1.

Duidelijk blijkt uit het medegedeelde hoezeer de Minangkabauer, evenals zoovele andere Archipelbewoners, gelooft aan een verwantschap tusschen menschen en dieren. Met dit leerstuk staat de menigte van pantangan's in verband, die men bij den Minangkabauer, evenals dit het geval is bij de rijst, ten opzichte van verschillende dieren aantreft, en waarvan wij er hieronder enkele willen opnoemen.

Pantang tegenover den tijger is het b. v.:

een weg te beloopen, die reeds langer dan een jaar niet meer betreden werd; - de tijger heeft zich dien tot voetpad gekozen en vindt het oneerbiedig als anderen dat ook doen.

desnachts, met andere personen op reis zijnde, achter elkander te ga an; - de tijger komt daardoor in de meening, dat men bevreesd voor hem is, en gevoelt zich daardoor gekrenkt;

zonder hoofddoek desnachts opweg zijn; - de tijger vindt daarin iets oneerbiedigs tegenover hem;

1 Bovengenoemde benaming van inji $\check{e}^{5}$ wordt ook gegeven aan de pokken, die men wel eens injiě pasana`an (pasanasan = bloedverwant, familielid, weerga, evenbeeld) hoort noemen, in de meening, dat zij dan minder verwoestingen aan het lichaam zullen aanrichten. 
op reis in den nacht, gedurig omkijken; - de tijger ziet hierin een teeken van angst;

het gloeiend einde van een stuk brandhout stuk slaan; - de rondspattende vonkjes doen aan het glinsteren van tijgerknevels denken, en het dier beschouwt dit als naäperij.

Het niet in acht nemen van deze en nog vele andere pantangans wekt den toorn van den injiěs balang, den tijger, zoodanig op, dat hij er dikwijls toe komt, den onvoorzichtige te verscheuren, en vandaar dat in dit geval de Minangkabauer zegt - zooals de Heer Van Hasselt reeds opmerkte - antah k ò s a la h, er zal wel een reden geweest zijn, doelende op het verzuimen dier voorschriften. Dit gezegde wordt echter niet toegepast op hem, die een poesar (kruintje) in den nek heeft, daar dit ongeluksteeken hem reeds lang voorspelde, dat hij eenmaal zulk een lot zou ondergaan.

Tegenover den olifant is het pantang:

hem gadjah (olifant) te noemen; - de titel van toean gadang ${ }^{1}$ of soetan bakaboeis ${ }^{2}$ is hem veel aangenamer;

hem, in het woud zijnde, schertsenderwijze uit te dagen; - hij verschijnt dan oogenblikkelijk;

met een toedoeăng 3 op 't hoofd veldarbeid te verrichten; - de olifant ziet er eene nabootsing van zijne ooren in.

Pantang is het tegenover een krokodil :

om kookpotten in de rivier te wasschen; - de krokodil acht zich daardoor beleedigd, meenende dat men hem de restantjes van het eten wil geven;

om veel beweging in het water te maken, als men het vaatwerk, waaruit gegeten is, reinigt; - dit wekt bij hem dezelfde gedachte op.

De twee laatstgenoemde pantangan's hebben betrekking op de leden van de Soekoe Piliang, hetgeen in verband staat met hetgeen hierboven gezegd is omtrent den wetgever Katoemanggoengan 4.

Een uitvloeisel van deze verwantschap is zeer zeker wel de mee-

${ }^{1}$ gadang = groot, voornaam.

${ }^{2} \mathrm{kaboe} \mathrm{i}^{\varsigma}=$ nevel, damp; nevelig, mistig; bakaboeis $=$ in nevelen gehuld.

3 toedoeăng $=$ hoed.

4 De pantangans ten opzichte van dieren zijn echter niet altijd een gevolg van het leerstuk der wedergeboorte, doch kunnen ook om andere redenen bestaan. Zoo is het voor de soekoe Djamba 5 b. v. pantang, om het vleesch van den yoeparang, een haaiensoort, te nuttigen. De stamvader van die soekoe toch, uit Makah (!) terugkeorende, leed schipbreuk, waarbij al zijn tochtgenooten omkwamen, en hij alleen door den visch gered en op het droge gebracht werd. 
ning, dat menschen uit dieren kunnen geboren worden, waarvan men een sprekend voorbeeld vindt in hetgeen de legende omtrent de eerste bevolking van Sumatra vertelt.

Soetan Sari Maharadjă di Radjŏ, zoo luidt hei in het kort, was de zoon van Soelthan Iskander Zoelkarnaini (Alexander de Groote). Met zijn broeder op reis zijnde naar het eiland Langkapoeri, wist hij zich, met behulp van zijn slimmen goudsmid Si Auli, van de gouden kroon zijns vaders meester te maken, waarna hij op Poelau Amèh (Sumatra) aankwam. Van dit groote eiland bestond toen nog niets dan de bergtop van den Marapi of Barapi; doch door het afnemen der zee werd er een nitgestrekt land gevormd, waarover zijne kinderen de gebieders werden. De vorst n.l. had een tijger, een hond en een kat bij zich, die, door Gods beschikking, ieder een kind ter wereld brachten, waarvan het eerste gebieder werd over A ga m, het tweede over Koeboeăng Tigor Baléh (XIII Kota's) en het derde over Limor Poeloeăh (L Kota's). Deze kinderen werden de stamvaders van de Minangkabausche bevolking der Padangsche Bovenlanden, en alleen de bewoners van Tanah Datar zijn uit 's vorsten huwelijk met een prinses afkomstig. Aan de waarheid van deze legende twijfelt de Minangkabauer niet, en hij, die dit doet, wordt o. a. gewezen op het kenmerkend verschil, dat er in den spreektoon en de stembuiging bestaat tusschen de bewoners van bovengenoemde landschappen.

Vanzelf zijn wij nu tot de vraag gekomen, of de Minangkabauer, als zoovele andere Archipelbewoners, de opvatting heeft, dat er ook uit planten menschen kunnen voortkomen. Rekening houdende met zijn geloof, dat er niet zoozeer eene zielsverhuizing, dan wel eene wedergeboorte plaats heeft, en er voor dit laatste, - ook al in verband met hetgeen er van het dier-geworden mensch verteld wordt, - een wezen noodig is, dat zich vrij bewegen kan en organen bezit zooals de mensch, moet men tot de conclusie komen, dat er van een dergelijke opvatting geen sprake kan zijn, althans tegenwoordig niet. Bij wien door mij dan ook onderzoek naar dit leerstuk werd ingesteld, een ieder verklaarde mịj, dat het niet bestond, en voor zoo verre mij bekend is, treft men in de Minangkabausche legenden geen voorbeelden aan, die bepaaldelijk op het ontstaan van menschen uit planten wijzen. Toch zou men uit de rol, die deze laatsten bij menschelijke geboorten somtijds spelen, besluiten kunnen, dat er in vroegere tijden eene andere opvatting moet hebben be- 
staan. Het zij ons vergund, dit met een paar voorbeelden aan te toonen.

Er was eens, zoo zegt de legende, eene arme maagd, die met slechts ééne borst geboren was. Op zekeren dag met een bundeltje biezen, die zij in het bosch gezocht had, huiswaarts keerende, gevoelde zij zich buitengewoon afgemat, en een onbeschrijfelijke dorst kwelde haar. Naast haren last een oogenblik terneergezeten, om wat uit te rusten, ontdekte zij op eenigen afstand een fraai gevormd keladiblad, waarop kristalheldere waterdroppels schitterden, en zij draalde niet, de droge lippen met dit kostelijk vocht te verkoelen. Eenigen tijd daarna, gevoelde zij, dat zij moeder moest worden, en toen ook hare kampoenggenooten de kenteekenen daarvan bij haar gewaar werden, wilden zij haar als eene ontuchtige vrouw steenigen en hare woning vernietigen. Iedere maal echter, dat zij voor dit doel uitgingen, werden zij door een hevig onweder overvallen, en noodzaakte een zware plasregen hen huiswaarts te keeren. Het knaapje, aan wien zij het leven schonk, werd reeds vroeg op de soerau ${ }^{1}$ gedaan, maar ofschoon het in ịver en aanleg boven al zijne medeleerlingen uitblonk, bleef de smet zijner geboorte aan hem kleven, en de verachting, die men hem en zijne moeder toonde, week niet, vóórdat hij gelegenheid had, den menschen te overtuigen, dat er bovennatuurlijke eigenschappen in hem sluimerden. Dit geschiedde, toen de dorpsbewoners een zwaren balk, voor den bouw eener moskee bestemd, naar het dorp wilden slepen, doch dien niet van zijne plaats konden krijgen, niettegenstaande er honderden uit al hunne macht aan trokken. Op dat oogenblik kwam de held der legende voorbij, en nu was een enkele aanraking met zijn staf voldoende, om het gevaarte met gemak in beweging te brengen. Dit wonder was genoeg, om hem en zijne moeder heilig te doen verklaren. I atere wonderen, door hem verricht, overtuigden de bevolking, dat hij werkelijk een ana $\mathrm{a}^{\mathrm{s}}$ indardjati was, d. w. z. geboren, zonder dat de moeder door een man bezwangerd is. Deze buitengewone man was de Toeankoe nan kiramat van Kota Gadang, de Heilige, van wien de Heer Gerth van Wijk reeds vertelde ${ }^{2}$.

Een ander voorbeeld vindt men in den bovengenoemden Tjindoer Matŏ. Maharadjŏ Lelo Pandjang Ramboei ${ }^{\varsigma}$, de vertrouweling van de

\footnotetext{
1 Bedehuis, gebouw waar de Minangkabauer de Qoran en andere godsdienstige geschriften leert lezen.

${ }^{2}$ Zie: Een Menangkabauwsche Heilige, door Gerth v. Wijk, Tijdschr. v. Ind. T. L. en $\mathrm{Vk}$.
} 
vorstin van Minangkabau, werd door deze eens uitgezonden om een klapper nioer balai te halen. Op den top van den boom gekomen, die deze vruchten droeg, werd hij door honger en dorst overvallen en maakte hij er voor zich een open, de stukken van de schaal naar beneden werpende. Een dezer stukken werd opgegeten door een buffel, die daardoor moeder werd van den stier $\mathrm{Si}$ B i n oe a n g; een ander werd genuttigd door een paard, dat den hengst Si Goe marang ter wereld bracht, en een derde door een kip, die aan den haan Si Kinantan het aanzijn schonk, drie dieren, welke in de legende, als menschen handelende, optreden. Nog eenige oogenblikken op den boom toevende, hoorde Maharadjŏ Lelŏ een geheimzinnige stem, die tot hem zeide, dat de vorstin zwanger zou worden, en dat het kind, hetwelk zij ter wereld zou brengen, geen gewoon menschenkind, maar dat van een afgezant Gods was. It o elah djas at sabanarnja, heet het verder, waarmede bedoeld wordt, dat niet de vleeschelijke omgang met een man de oorzaak der geboorte zou zijn. Zoo zou ook Kambang Bandahari, een der hofjuffers, onder dezelfde omstandigheden, een kind ter wereld brengen, want, staat er: tidas lain $t i d a^{5}$ boekan, dari awal sampai sakarang barang mamakan nioeă balai, d. i.: "zoo en niet anders is het door alle tijden heen geweest met ieder, die van de nioer balai at". Maharadjŏ Lelŏ Pandjang Ramboei ${ }^{\varsigma}$ bracht vervolgens een klapper naar het paleis, waar de vorstin en Kambang Bandahari er ieder een deel van opaten. Zoo kon dan ook de Toeankoe, de zoon van de vorstin, tegen Tjindoer Matǒ, de zoon van Kambang Bandahari, zinspelende op deze omstandigheid, later zeggen, dat zij wel twee lichamen, doch slechts één ziel hadden, toeboeăh doeŏ nja ónjŏ satoe, en op hetzelfde oogenblik sterven zouden, adiès mai $i^{\varsigma}$ denai poen kapan.

In het derde hoofdstuk van zijne verhandeling wijst Dr. Wilken er op, hoe uit de beschouwing, dat het leven hiemamaals slechts eene voortzetting is van het aardsche, de zoogenaamde doodenofters zijn voortgevloeid, welke door de nagelaten betrekkingen gebracht worden uit vrees, dat zij anders door de geesten verontrust en gekweld zouden worden. Deze doodenoffers onderscheidt hij in die, welke bij en welke vóór en ná de begrafenis plaats hebben. De eersten moeten voorzien in de behoeften van de ziel in het hiernamaals, de anderen zijn bestemd om door haar op aarde te worden gebruikt. Dr. Wilken zet verder nauwkeurig uiteen, hoe de menschen-, dieren- en plantenof- 
fers, ja zelfs de offers van levenlooze voorwerpen, in verband staan met de voorstelling, dat alles bezield is, terwijl hij er verder op wijst hoe de dierenoffers anleiding gegeven hebben tot de doodenmalen en doodenfeesten.

Wat er van deze offers en feesten onder den invloed van den Islam geworden is, en welke beteekenis zij verkregen hebben voor de stammen, die dezen godsdienst belijden, dus ook voor de Minangkabauers, behoeft wel geen betoog. Het zijn voor hen, schrijft Dr. Wilken, geen offers meer aan, maar voor de dooden, opdat hunne zielen rust vinden en bij God in genade worden aangenomen. De offeraar verbindt daaraan intusschen terstond het verzoek voor zichzelven, dat de overledene zijn voorbidder zij bij Allah, en is tevens daarbijgedachtig aan de gansche schaar zijner voorouderen, van onze eerste stamouders af, en van alle profeten en heiligen van den Islam.

Bij de Minangkabauers bestaan, als overblijfsel van het oude geloof, in hoofdzaak niets meer dan de doodenmalen, die, gelijk door Dr. Wilken, naar aanleiding van de geschriften van de Heeren Van Hasselt en Verkerk Pistorius, reeds vermeld is, den 3 den, 7 den, $40^{\text {sten }}$ en $100^{\text {sten }}$ dag na het overlijden gegeven worden, en de gewoonte, elk jaar, in de maand sja'bân, ter eere van alle afgestorvenen feest te vieren en de graven van onkruid te reinigen. Gaat men echter de gebruiken na, die, zij het dan ook sporadisch, naast deze doodenmalen plaats hebben, dan ontmoet men nog duidelijk de sporen, die aanwijzen hoe in zekeren zin nog offers gebracht worden a an, en niet voor den doode, al is de Minangkabauer zich daarvan niet meer bewust, en al stelt hij er ook veel van op rekening van het Mohammedanisme, waarvan trouwens de meesten slechts eene zeer oppervlakkige kennis hebben.

Is er iemand in eene andere negorij gestorven, en kan hij in zijn eigen kampoeng niet begraven worden, dan is het in sommige streken de gewoonte, dat de ouders van den overledene met de andere familieleden de hilau laten uitvoeren. Hieronder verstaat men een dans door vrouwen - gewoonlijk bloedverwanten en goede kennissen van den doode - uitgevoerd, waarbij o. a. de lotgevallen van den gestorvene bezongen worden. Gewoonlijk heeft deze feestelijkheid plaats eenige dagen na het ontvangen van de doodstijding, en wel eerst in de woning der ouders, daarna in die van het oudste familielid en eindelijk in het openbaar. De danseressen worden alleen op sirih en tabak onthaald en krijgen geen eten, omdat, zegt de Minangkabauer, droefheid belet dit laatste klaar te maken, m. i. echter 
eigenlijk, omdat de ziel van den betreurde afwezig is en daarom toch niet van de gerechten kan nuttigen. Op sommige plaatsen wordt de hilau echter ook gehouden voor personen, die in hun eigene kampoeng gestorven zijn, en wel voor aanzienlijken.

In Oud-Agam is het gebruik, dat er bij de doodstijding tevens het een of ander kleedingstuk van den in den vreemde overledene wordt toegezonden, dat dan bij de doodenfeesten op den 3den, 7 den, enz., dag telken male te voorschijn gehaald wordt en neergelegd of opgehangen in het vertrek, waar het mando'a plaats heeft, blijkbaar als vertegenwoordiger der ziel van hem, die is heengegaan.

Deze en dergelijke ceremoniën doen dus $\mathrm{m}$. i. ook denken aan de opvatting, dat de ziel niet tot rust komen en het groote zielenrijk binnentreden kan, alvorens de nabestaanden zich van hunne plichten omtrent haar gekweten hebben. De Minangkabauer noemt dan ook het vervullen van de verplichte diensten ten opzichte van een doode eigenaardig mangardjati ${ }^{1}$.

Er is echter meer. Zoo wordt in Soengai Pagoe de overledene gekleed in zijn beste kleeren, en worden naast hem zijn kris en gouden en zilveren sieraden gelegd, terwijl andere kostbare kleedingstukken van hem in de lijkkamer worden opgehangen of ten toon gesteld. Is de afgestorvene een aanzienlijke geweest, dan wordt zijn lijk niet zelden eerst naar de moskee gebracht, alwaar men laat sa m ba hjang, of, om zoo te zeggen, een lijkdienst of mis houdt. Vroeger bestond daar tevens de gewoonte, de doodenmalen, op de boven angegeven dagen, op het graf-zelf te geven; doch is men langzamerhand er toe overgegaan, om dit in huis te doen, aangezien het - zegt de Minangkabauer - zoo lastig was, de spijzen daarheen te brengen en men dikwijls van den regen, enz., te lijden had. Ook hier komt dus duidelijk het oude geloof voor den dag, dat n. l. den overledene de reis naar de eeuwigheid moet vergemakkelijkt worden en hem de ziel van het geofferde daarbij van nut is.

Duidelijker nog blijkt dit uit sommige ceremoniën, zooals die nog hier en daar bij een sterfgeval in het Soloksche bestaan. Alvorens dat het lijk gewasscheu wordt, wordt het door sommige vrouwelijke familieleden, onder het weeklagen van eenigen en het in-zwijmvallen van anderen, van het begin naar het einde der woning gedragen. $\mathrm{Na}$ de wassching, wordt het lijk in de kleeren gestoken en op een praalbed tegen fraaie kussens gezet, onder tentoonstelling van al hetgeen de

${ }^{1}$ In verband met $k a d j o(k e r d j a)=$ werk, bezigheid, drukte.

5e Volgr. V. 
overledene aan kostbaarheden bezat. Is de doode eene vrouw, dan worden naast het hoofdkussen eenige schoteltjes geplaatst, die later als geschenk dienen aan hare aangetrouwde familieleden en aan de oerang nan manjandarnjŏ 1 .

Indien het overlijden in den namiddag plaats heeft, wordt het lijk één nacht overgehouden, in welk geval er niet in het sterf huis, doch in eene andere woning gegeten wordt, terwijl in dien nacht de doode een damarkaars naast zich krijgt. Jedere vrouwelijke bloedverwante, die den volgenden morgen van verre komt, brengt een stuk lijnwaad voor het doodskleed mede, en, na het gewone $\mathrm{man}$ gadjikan mais, gaat men dikwijls over tot het $\mathrm{marati}^{\varepsilon} \mathrm{taga}^{\varsigma}$, mede eene soort van doodendans, waarbij zoo hard mogelijk op den vloer der woning wordt gestampt. Zoo ook wordt het lijk, alvorens het grafwaarts gaat, door de bloedverwanten van het hoofd tot de voeten gewreven, onder den uitroep van elò elò badjalan sajang djangan tarambè tabalintang, d.i.: "moogt ge zoo rustig mogelijk uwe reis maken, lieveling, en uwen weg ongestoord vervolgen!"

Nog is het in evengenoemde streken de gewoonte, om het lijk, nadat de reiniging heeft plats gehad en het in de faaaiste kleederen gestoken is, de lippen met sirihspeeksel rood te verven en het een aangestoken sigaar in den mond te geven, zoodat de doode geheel het voorkomen van een bruidegom heeft, vooral als men hem te voren de haren heeft gekamd en deze met olie besmeerd heeft, en hem, met een scherm boven het hoofd, tegen een stapel van fraaie kussens heeft geplaatst.

Het uitvoeren van de hilau is, evenals het opschikken van het lijk, overigens vrij algemeen, en zoo ook de gewoonte, dat vrouwen den doode omringen en hem weeklagende allerlei boodschappen opdragen aan de zielen van vroeger gestorvenen.

Bij het feest op den $3 \mathrm{n}$ en $7 \mathrm{n}$ dag, waarvan het tweede grooter is dan het eerste, brengen de vrouwen ieder een hoeveelheid rijst mede, die door de mannen wordt genuttigd, doch waarvan de beteekenis wel zal zijn, dat ook de afgestorvene het zijne krijgt.

Ten slotte mogen wij blijkbaar ook sporen van de oude opvatting zien in het gebruik, dat hier en daar bestaat, om, zooals de Heer

1 Van sandar; manjandar = steunen, medehelpen; een gewoonte of voorschrift onder de Minangkabausche vrouwen, om, bij den dood van eene bloedverwante of vriendin, gedurende eenigen tijd, gewoonlijk zeven dagen, in het huis van den overledene te helpen, en onder de mannen, om, als er een man gestorven is, gedurende drie jaren, van tijd tot tijd iets aan zijn kinderen te schenken. 
Van Hasselt meedeelt, op het grootste doodenfeest, - dat op den hondersten dag, - huisraal, zooals borden, matten, mandjes, en verder vleesch en rijst ten gesehenke te geven. Dit gesehiedtaan bloedverwanten, vrienden en bekenden van den werledene, doch zal wel als eene wijziging beschouwd kunnen worlen van cen vroeger bestand hebbend gebruik, om, zooals het in sommige streken van den Arehipel nog de gewoonte is, deze voorwerpen op de graven te plaatsen.

\section{II.}

\section{Fetirgisme. - Spinitisme.}

Aan het begin van het vierde hoofdstuk zijner verhandeling wijst Dr. Wilken ex op hoe nit het dogma, dat alles bezield is, het fetissisme, en uit dat, hetwelk een vrij-zijn der zielen aanneent, het spiritisme vootspruit. Tussehen spiritisme en fetissisme bestaat er, zooals wij dase lezen, geen onderseheid. Hetgeen in beide gevallen anngebeden worlt, is de ziel, de geest, doeh bij het laatste worlt de geest geheel met het voorwerp, warin hij huisvest, vereenzelvigd, daarvan niet onderscheiden, zoodat het feitelijk het voorwerp is, dat als een bezield en machtig wezen vereerd wordt. Verder onderscheidt Dr. Wilken de voorwerpen, die in de bezielde en onbezielde natuur als fetissen worden beschouwd, in twee groepen, die, welke in het bezit zijnde van enkele individuen, alleen voor deze fetissen zijn, en die, welke door niemand bezeten, door ieder als fetis vereerd worden.

Wat den Minangkabauer betreft, vindt men van de eerste soort van fetissen een merkwaardig voorbeeld in de rijkssieraden van den Toeankoe van Pasimpai in de Padangsche Bovenlanden, van welker vereering men de beschrijving leest in het werk over MiddenSumatra van den Heer Van Hasselt. Enkele andere voorbeelden mogen nog nader doen zien, hoezeer het geloof, aan de bovennatuurlijke krachten van sommige knnstvoorwerpen bij den Minangkabauer heerschende is.

In de boven reeds aangehaalde legende Tjindoer Matŏ is de vorstin van Tandjoeng Boengǒ, in het rijk van Minangkabau, in het bezit van een kain, doek, die, uitgespreid, het geheele rijk besloeg, en, opgerold, zoo groot was als een nagel. Dat kleedingstuk was geweven door een nimf, die jaarlïks slechts één slag op het weeftoestel deed, terwijl de kain zichzelf inspoelde. Die vorstin had tevens een heilige kris, Madang Géri genaamd. 't Gevest daarvan was van khamat-hout gemakt; 't wapen-zelf was in drie stukken verdeeld, waarvan er een in 
Roem, een in China, en een op Sumatra zich bevond, terwijl de vereeniging dezer deelen het einde der wereld voorspelde. Het baadje van de vorstin had eveneens bovennatuurlijke kracht; het was een erfstuk van deu profeet Adam, en engelen hadden er de stof van geweven. Het wondergoud, dat haar toebehoorde, deed den draagstok, waarmede men het vervoeren wilde, breken. Behalve de genoemde, had zij nog een menigte andere voorwerpen, die, door hunne bovennatuurlijke geaardheid, allen als heilig werden beschouwd.

Evengenoemde kris Madang Géri werd, zooals men verder leest, bewaard in een doos van paarlemoer en moest zeer eerbiedig behandeld worden, wijl zij ongeluk aanbracht, als men over haar heenstapte, en de beenen verlamde, als men vóór haar heenging. In het vertrek, waar zij bewaard werd, lag nog een andere, $\mathrm{S}$ ampŏnŏ Gandjŏ érah geheeten, benevens een ring, tjintjin tjan a gŏ, waarvan men niet kon zeggen of hij van goud dan wel van zilver, van rood of van geel koper was, en die tot de nalatenschap van den vorst van Roem behoorde. Indien deze voorwerpen uit de schatkamer gehaald moesten worden, werd deze eerst bewierookt en met gele rijst bestrooid, waarna de deur der bewaarplaats, onder het doen van een gebed, geopend werd. Onder de verschillende artikelen, als heilige po es a k ŏ's ${ }^{1}$ door de vorstin in eere gehouden, behoorde ook een kain, die een nabootsing was van de Sandoesin, die men in den hemel makte. Van den gordel, die er bij behoorde, leest men, dat de stof er van was gesponnen door oerang ba paroeăh ${ }^{2}$, uitgeplozen door o erang baris ang ${ }^{3}$, en geweven door garagasi 4. In 't water was er de eerste hand aan gelegd, eu in 't vuur was hij afgewerkt; uitgerold, besloeg hij 't geheele rijk, opgerold, was hij zoo groot als een nagel; oorspronkelijk van Roem afkomstig, was zij meêgebracht door de zwaluwen. De ring Tjanagǒ ta roeăhan deed, door zijn flonkeringen, de onderdanen op de knieen vallen. Van een der krissen heet het, dat zij hinnikte, als zij in de schede gestoken, en bromde, als zij er uitgehaald werd; de punt er van had zichzelve gevormd en zat vol vergif; als haar lemmet een weinig uit het hecht week, was er een jaar lang zulk een droogte, dat er verscheidene dieren en planten stierven. Het vergif was van den hemel afkomstig; de persoon, wiens schaduw slechts er mede in aanraking kwam, moest dit reeds

1 Erfstuk, erfenis.

2 Oerang baparoeah = menschen met een snavel.

s Oerang barisang = mensehen met kieuwen.

4 Garagasi $=$ reuzen. 
met den dood bekoopen. Evenzoo werd aan de vorstelijke pajoeng een bovennatuurlijke kracht toegeschreven. Niet minder was dit het geval met de heilige Agoeng Ganta Alam, het geweer Allah Oerabi en verschillende taboeh's in het rijk, door het geluid van welke voorwerpen geheel Pagar Roejoeng in opschudding kwam, het water in de Soengai Boengŏ begon te zwellen, de dakranden der woningen zich naar boven bewogen, de fondamenten zich verplaatsten, de planken bogen, en de heilige klapperboomen heen en weder wuifden, zoodat men dacht, dat het einde der wereld daar was.

In de geschiedenis van Soetan Manangkérang komt een zwaard voor, Djanawi geheeten, dat sprak, als men het uittrok, en bromde, als men het in de schede stak, en een rentjong, soort van tweesnijdend mes, dat wegsprong, nadat het tot zijn meester had gezegd: "Laat mij los, ik zal Mahajoen Boeki ${ }^{\varsigma}$ dooden", terwijl in het verhaal van Prinses Balkis o. a. gesproken wordt van een doek, die nooit gebruikt werd, een erfstuk van den geestenkoning was, en den dood veroorzaakte aan den persoon, die hem omsloeg.

Doch behalve kunstvoorwerpen, zijn er tal van objecten uit elk rijk der natuur, die, naar de voorstelling van den Minangkabauer, bovenaardsche krachten, gelukaanbrengende of onheilveroorzakende eigenschappen, bezitten, batoeah of tilak ŏ zijn, gelijk dit heet. Somtijds hangen deze eigenschappen van eigenaardige kenteekenen af. Bij de katitiran's, balam's en poejoeh's, de hanen en andere vogels, zijn het de plaatsing der teenen, de schubben aan de pooten en de kleur der vederen; bij paarden en andere viervoetige dieren, de zoogenaamde poesar's; bij vrouwen, behalve dergelijke poesar's, ook de wijze van haargroei; bij wapenen, de spatten, vlammen en scheurtjes in het staal, waarvan zij zijn vervaardigd. Waar het noodig geacht wordt, zooals o. a. bij de hanengevechten, kunnen die bovennatuurlijke eigenschappen worden uit- of aangeroepen, hetgeen de Minangkabauer manjaroekan noemt, en waarover bijna in elke legende gesproken wordt.

Dat het gebruik van amuletten algemeen is bij den Minangkabauer, behoeft nauwelijks te worden gezegd. Een amulet, waarop o. a. veel prijs gesteld wordt, is de rantai koendies, waarvan in de Mandjau Ari wordt verteld, dat zij onkwetsbaar maakt; een ander is de ring tjinto-tjinto, die zijnen bezitter alles doet verkrijgen, wat deze verlangt, en die als een vader en moeder voor hem zorgt. Moentiko's of bezoarsteenen, welke o. a. gevonden worden in den kop van een slang of in waterputten, zijn insgelijks 
voorwerpen van heilige vereering, en zoo ook de ren ŏ, een buitengewoon glanzend stukje been in het voorhoofd van den tijger, of een met hellen gloed glinsterend gedeelte in het goud 1. Nog moet, hoewel deze geen amulet in den strikten zin des woords is, immers niet als een gelukaanbrengend of onheilwerend middel gedragen wordt, de batoe pandape $e^{\varepsilon}$ n hier genoemd worden, een koperkleurige steen, in vroegere tijden gevonden en zorgvuldig bewaard, om gebruikt te worden, wanneer iemand zijn toekomstig lot wil onderzoeken. In hoeverre dit gunstig dan wel ongunstig zal zijn, blijkt uit de omstandigheid, of de proefnemer den steen niet dan wel tot eene zekere hoogte kan oplichten. Hoe eindelijk de katitiran een amulet is, waarvoor groote eerbied gekoesterd wordt, is door mij reeds elders uitvoerig medegedeeld 2 .

Tot dusverre werd hoofdzakelijk alleen gewezen op zaken, die fetissen zijn voor enkele personen. Thans willen wij enkele voorwerpen noemen, die, aan niemand toebehoorende, door een ieder als fetis kunnen worden beschouwd.

Naar de voorstelling van den Minangkabauer, zijn er tal van voorwerpen, waarin of waarbij geesten, zoowel kwade als goede, huizen. Zij zijn bahoenji - bewoond - gelijk dat heet. Een gevolg van dit bahoenji is, dat die voorwerpen sati (= sakti), dat is: met bovennatuurlijke macht of kracht toegerust, zijn. Zoo zijn de batoe nan mandaroe $i^{s}$, geluidgevende steenen, bahoenji en dus sati : zulk een steen wordt toch gezegd de woonplaats te zijn van een geest of van een oerang wali, een vertrouwde of vriend Gods. Zoo vindt men bij Kota Gadang de zoogenaamde ba t o e ba koetjiĕng, een steen, waaraan men, met eene eenigszins sterke verbeeldingskracht, den vorm van eene kat kan onderkennen. Ook deze steen is sati, kan o. a. regen schenken, waarom men hem wel eens met kippenbloed besmeert, en, onder het prevelen van eene tooverformule, wrijft en bewierookt.

Wat de planten betreft, uit de ceremoniën ten opzichte van de rijst in acht genomen, heeft men reeds kunnen zien, hoezeer deze laatste voor den Minangkabauer een voorwerp van fetistische vereering is.

1 Volgens sommigen beteekent ren o, ook : de geheimzinnige glans, die er uitgaat van plaatsen, waar zich dingen bevinden, waarvoor de Minangkabauer grooten eerbied koestert, en welken glans hij wel eens ontwaart daar, waar veel goud in den grond zit, of zich veie tijgers ophouden.

2 Van der Toorn, Iets over het Batoeah en Tilako bij de Maleiers, Tijdschr. v. Ind. T. L. en Vk., dl. XXVI. 
Behalve de rijst, worden nog verschillende andere gewassen als heilig beschouwd, en het zich-in-bezit-stellen daarvan gaat met de ongelooflijkste moeite gepaard. Zoo leest men b. v. in de Tjindoer Matŏ van een limau poeroet, die bij een grooten steen aan een bron groeit, en waarvan er zeven vruchten aan één tak zitten, overhangende naar het Oosten. Hij, die ze gaat halen, moet vooraf driemaal tegen den stam schoppen, den adem inhouden, en dan eerst naar boven klinmen. Hij mag de vruchten niet met de handen aanraken, maar moet ze in den mond naar beneden brengen, en een volmaakt stilzwijgen bewaren, als iemand in die oogenblikken iets aan hem vraagt. De stukken van deze limau's, met andere ingrediënten, als toovermiddel gebruikt om een blik in de toekomst te werpen, voorspellen, in hunne bewegingen, zoowel goed als kwaad, en kunnen alle gevaren der wereld verdrijven.

Hierboven maakten wij reeds gewag van de klapper nioer balai ${ }^{1}$ en leerden wij de gevolgen kennen, welke het eten daarvan, volgens de legende, placht te hebben. De boom, waaraan deze klapper groeide, was, zoo wordt er verder verteld, zoo hoog, dat zijn kruin tot aan het hemelgewelf reikte. Aan zijn wortels kronkelde een draak, aan zijn stam een slang, in zijn vruchtentros kakelde een tadoeăng, aan zijn takken lekte een oepa, aan zijn bladnerven hingen wespen, en vergiftige bijen bromden er-om heen. Al deze dieren moesten den boom bewaken. Alvorens dat de persoon, die de vrnchten er van ging halen, naar boven klom, werl er door een priester voor zijn behouden terugkomst gebeden, want zeven dagen zou het duren voor hij terug kon zijn. Toen de vorstin van het Minangkabausche rijk een der vruchten met de heilige kris Koelah kamar openmaakte, brak deze in drie stukken.

De talang parindoe - eene denkbeeldige bamboesoort waarvan eveneens in de Minangkabausche verhalen veel gesproken wordt, groeit op de toppen van eenzaam gelegen bergen en brengt een zacht weemoedig geluid voort, dat den hoorder beweegt er op af te gaan. Wie zoo gelukkig is, die tooverplant te vinden, kan zich verzekerd houden van buitengewonen voorspoed.

Niet alleen in geschriften worden sommige planten als heilig beschouwd, ook in den mond des volks zijn zij dit. Een voorname plaats onder de boomen b. v. bekleedt de baring in, waarvan de vele groote en dichte luchtwortels een stil en rustig verblijf aan de

1 Ook wel kalapŏ nioeà gadiěng genoemd. 
geesten bieden. Menigmaal ziet men dan ook zulk een woudreus omgeven door een stevige schutting, opdat menschenkinderen het daar niet te druk zouden maken. - Een geheel denkbeeldige boom is de baringin sonsang, wiens bladeren met de ruwe oppervlakte naar boven gekeerd zijn, en die, op de maan groeiende, tot lusthof dient van jonggestorven kinderen, welke er door bidadari's worden heengebracht en neergelegd in gouden wiegjes, hangende onder den rijken bladerdos. - De kajoe ramang is een boom, die vooral tot zetel van booze geesten strekt, en daarom zulk een groote vrees inboezemt, dat men in het donker niet gaarne in zijne nabijheid komt. - Bij Lasi, een kampoeng op 4 à 5 palen afstands van Fort de Kock, lag vroeger, in de bedding van de daar voorbijstroomende rivier, een boom, die, bij den doorbraak op den top van den Marapi in 1882 (?), geheel onder het afgevoerde zand was bedolven. Deze boom was het voorwerp van eene heilige vereering bij de bewoners der omliggende dorpen. $\mathrm{Zij}$, die de eene of andere vrome bedoeling hadden, gingen er bidden en offeren, en zagen het voorwerp hunner vereering, als teeken dat het met hen meedeed, zich eenigszins oprichten en nederbuigen.

Werden er van de dieren hiervoren reeds eenige opgenoemd, die voorwerpen van fetistische vereering zijn, vele zijn er nog, welke, zonder dat bepaaldelijk te wezen, door de bevolking als heilig beschouwd worden. Zoo leest men in de Mandjau Ari omtrent den vogel Bora ${ }^{\varepsilon}$ (marak), dat hij onder het aansteken van een reukoffer aangeroepen werd, om den gestorvene Moerai Randin tot het leven terug te brengen. Nadat hij uit den hemel naar beneden gekomen en door Rangin Paménan met eene zware vervloeking bedreigd was, liet hij aïĕ mawa en zeven klappernerven achter, als middel om Moerai Randin weer levend te maken. Hij wordt beschreven als "een vogel met еeв baard; zijn vederen zijn beschilderd met goudwater, zijn vleugelen afgezet met as ŏ, zijn snavel is van goud. Het geluid, dat hij onophoudelijk met bek en snavel maakt, klinkt als de poepoet en de saroenai, en doet denken aan den klank der talempoeng van de Javaansche vorsten". Ook in andere verhalen komt de Boras of Mara voor, o. a. in de Poeteri Balkis, gelijk wij hiervoren gezien hebben, waar hij als afgezant dienst doet bij de prinses en bij Soelaiman.

Bekend is de vrees, die men koestert voor den boeroeng hanto e, den nachtuil, door den Minangkabauer beschouwd als de voorbode van den geest, die den mensch zijn stervensuur aankondigt. Voor dien uil is men zoo bang, dat men, bij het vernemen van zijn 
geluid, de deken, waaronder kleine kinderen liggen, uitschudt. Zoo ook maakt de moerai, wiens geroep anders het aanbreken van den dageraad verkondigt, van tijd tot tijd een geluid, waarin de Minangkabauer duidelijk pitjiĕng $=$ dichtknijpen, van de oogen, hoort, ziende dit voor hem op een nabijzijnd sterfgeval. - De lawah en bingkaroeng mogen niet gedood worden, doch de tjatja wel. Dit grondt zich op eene gebeurtenis, den profeet overkomen. In een oorlog moest hij n.l. voor den vijand vluchten, en verschool hij zich in een spelonk. Terstond weefde een spin haar web voor de opening, en wischte een bingkaroeng zijn voetsporen uit. Een tjatja ${ }^{\varsigma}$ echter, in het hol haar verblijf houdende, beging de onvoorzichtigheid te schreeuwen, zoodat indien de vervolgers door het spinneweb niet de overtuiging gehad hadden, dat de vluchteling daarbinnen niet zijn kon, het met den grooten man gedaan zou zijn geweest. Ook visschen kunnen als heilig beschouwd worden. Op een menigte plaatsen in de Padangsche Bovenlanden vindt men vijvers, waarin zij gehouden worden. Een voorbeeld daarvan zagen wij reeds hierboven. - Overigens zijn het, onder de viervoetige dieren, vooral de driekleurige, of die welke om het lichaam een ring hebben van afstekende kleur - witte beesten gewoonlijk een zwarten, en zwarte het liefst een witten - die min of meer in een reuk van heiligheid staan en speciaal geluk aanbrengen. Zoo koesterden mijn bedienden voor koetjiĕng balang eene zekere voorliefde ten opzichte van de andere katten in mijne woning.

Hoezeer de bevolking nog doordrongen is van de heiligheid en de bovennatuurlijke krachten in dieren aanwezig , daarvan was ik o. a. zelf getuige, tijdens mijn verblijf in de Padandgsche Bovenlanden. In het jaar 1882 of ' 83 , meen ik, was er in de nabijheid van Padang Pandjang eene koe, die het voorwerp van eene algemeene vereering was. Dagelijks kwam er eene ontelbare menigte op, om van het dier genezing te erlangen voor allerlei kwalen. De genezende kracht ging uit van de tong, waarmede de koe het zieke of verwonde deel lekte. De vergoding was zelfs zoo groot, dat velen zich alle moeite gaven, om de uitwerpselen van het dier machtig te worden, ten einde die voor hetzelfde doel aan te wenden ${ }^{1}$.

Als een voorbeeld dat menschen beschouwd kunnen worden met bovennatuurlijke macht begaafd of heilig te zijn, en als zoodanig

\footnotetext{
1 Artikelen daarover zullen hoogstwaarschijnlijk nog wel te vinden zijn in de Sumatra Courant van den Heer Chatelin.
} 
vereerd worden, wijst Dr. Wilken op den vorst van Bangkara, die voor de Bataksche stammen als een godheid optreedt. In de reeds meermalen genoemde legende van Tjindoer Matŏ vinden wij telkens een dergelijke opvatting omtrent den Toeankoe. Van dezen leest men, dat hij de ledematen verlamde, als men over hem henen stapte, de tong verstijfde, als men zijn naam uitsprak, en blind maakte, als men hem aanstaarde. Toen hij op reis ging naar Soengai Tarab, hadden er allerlei wonderen plaats: zoo liet op dat oogenblik een enkele donderslag zich hooren, en werd de glans van den bliksem weerkaatst tot ver in den omtrek, waardoor de bevolking in aanbidding op de knieën zonk. Waar, in een ander gedeelte van het verhaal, Si Barakat werd uitgezonden, om een pisang tongga te gaan zoeken, was het, naast de beschikking van God, de heiligheid van den vorst, welke hem deze vrucht deed vinden. Nog in meer gevallen was het aan de bovennatuurlijke eigenschappen van den Toeankoe toe te schrijven, dat het een of ander bereikt werd.

Soelaiman, wordt in de Poetri Balkis genoemd "de profeet Gods, de beheerscher der wereld, die rijk was boven alle beschrijving en aan wien alles onderworpen was; de ruischende wind gehoorzaamde hem; de wilde vogels, de dieren des wouds, de yisschen in de zee, de geesten op de eilanden waren hem onderdanig. Soelaiman kon op de wolken wandelen, daartoe werd hij door den wind opgevoerd; wanneer hij wilde opstijgen, werd een geelkoperen zitmat voor hem uitgespreid; hij steeg er op met de rijkssieraden en honderden menschen; dan kwam er een gunstige wind, die den man hoog in de lucht opvoerde".

Van zulk een geloof aan de bovennatuurlijke eigenschappen van iemand en de daarmede gepaard gaande vereering van diens persoon, trof ik, eenige jaren geleden, een merkwaardig geval aan in de Padangsche Bovenlanden. In dien tijd reed men n. l. te Fort de Kock en in de omstreken, in een kinderwagentje, een knaap rond, die gezegd werd drie à vier jaar oud te zijn, doch die naar gissing minstens zeven of acht moest wezen. Van dat kind werd verteld, dat het spreken kon, toen het ter wereld kwam, en dat het op den leeftijd van drie jaren den Qoran zoodanig uit het hoofd kende, dat het er een tal van spreuken uit wist op te zeggen. Van die spreuken had hij er een menigte, op strookjes papier geschreven, bij zich, die door hem onder de schare van bezoekers uitgedeeld werden, en geheel als a djimat werden beschouwd. Het voertuigje, waarin de knaap werd voortgeduwd, was steeds omringd 
door een menigte personen, die hem over allerlei zaken om raad kwamen vragen, en er ten zeerste op gesteld waren, een amulet van hem te ontvangen. Menschen van verschillenden leeftijd hielden gesprekken met hem, en waren opgetogen over zijn wijsheid en zeggingskracht.

Van den Heilige van Kota Gadang, hierboven reeds genoemd, vinden wij nog vermeld, dat hij, in een gebed bezwijmd geraakt zijnde, op zee een scheepje zag. waarvan de opvarenden met een hevigen storm te kampen hadden. Bïgekomen, was hij in de volle overtuiging de schepelingen gered te hebben, en dat hij werkelijk op zee vertoefd had, kon men zien aan het zilte water, dat hem uit de kleeren droop. Nog duidelijker bleek dit echter, toen de geredden hem eenigen tijd later, onder aanbieding van rijke geschenken, hun innigen dank kwamen brengen. Gevolg gevende aan zijn plan, een bedevaart naar Mekka te doen, om vandaar een heilige goeng te halen, ondernam hij die reis op een zitmatje, na vooraf v́an zijne kampoenggenooten de belofte verkregen te hebben, dat men, zoo zijne moeder intusschen mocht sterven, tot zijne terugkomst wachten zou met haar te begraven. Acht dagen later reeds was hij, met de goeng bij zich, weder in zijn dorp, doch vernam daar, dat zijne moeder reeds begraven was. Bedroefd en vertoornd over het schenden der belofte, slingerde hij het voorwerp van zich, dat later op verren afstand in een rijstveld teruggevonden werd 1.

$\mathrm{Na}$ hetgeen wij hierboven medegedeeld hebben omtrent het "lagere fetissisme", zooals Dr. Wilken dat noemt, ligt het vanzelf op onzen weg, eenige oogenblikken stil te staan bij het hoogste: den dienst der hemellichamen, en wel in de eerste plaats dien van den hemel of de zon in betrekking tot de aarde.

De mythe van het huwelijk tusschen hemel en aarde, die op de Zuid-Oostelijk gelegen eilanden van den Archipel zulk een voorname rol speelt en daar bepaaldelijk zich tot een eeredienst heeft ontwikkeld, wordt bij den Minangkabauer niet aangetroffen, iets, wat na de zoo duidelijke verklaring van Dr. Wilken omtrent den oorsprong dier mythe, eigenlijk onnoodig was te vermelden. Dit neemt niet weg dat de anthropopathische opvatting van de aarde, den hemel,

1 Van den Heilige, die plotseling verdween, hoorde men sedert niets meer; de goeng echter wordt bewaard in de Soekoe Si Koembang, en heeft tot heden nog het vermogen, den klank van al hare zusteren in de nabijheid dof te maken en te verzwakken. 
de zon en de maan voorheen moet hebben bestaan. Wat de aarde betreft, blijkt dit o. a. uit de vervloeking, die men over zichzelf uitspreekt, wanneer mẹn de waarheid van het een of ander bevestigen wil. Indas ditarimŏ boemi dèn, dat is: ik moge door de aarde niet ontvangen worden (als dit of dat enz.), pleegt men dan namelijk te zeggen. Blijkbaar gaat men daarbij uit van de meening, dat de aarde, denkend, gevoelend en willend, te heilig zich acht, om een meineedige in haren schoot op te nemen. Hoezeer de zon en de maan als persoonlijke, mannelijke en vrouwelijke, met elkander in het huwelijk verbonden wezens gedacht worden, blijkt uit enkele zegswijzen. Zoo leest men in de Poeteri Balkis, blz. 48: "De prinses ging naast den koning zitten, evenals de maan naast de zon, en geen vrouw kon met haar vergeleken worden". Op blz. 54 heet het, waar de pauw met de prinses over vorst Solaiman spreekt: "Ik zie in mijn geest $\mathrm{u}$ en Solaiman vereenigd, gelijk de maan met de zon", terwijl op blz. 63 vermeld staat: "En toen nu prinses Balkis met Solaiman gehuwd was (en zij vereenigd waren) als de maan en de zon, omhelsde Balkis het ware geloof" 1. Kan het uit de aangehaalde voorbeelden blijken, dat men

1 In dit opstel hebben wij herhaaldelijk voorbeelden aangehaald uit de Poeteri Balkis. De vraag zou nu knnnen worden gedaan, of men, ten aanzien van die voorbeelden, wel met opvattingen van den Minangkabauer te doen heeft, aangezien de schrijver van dat verhaal zelf meedeelt, dat hij dit "getrokken heeft uit de heilige overleveringen", en "men den oorsprong daarvan vinden kan in die van den profeet Soeleiman." De Heer Gerth van Wijk wijst er op, hoe die schrijver een vrome geloovige, een malim, was, die de bedoeling had, de heidensche lectuur, zooals de Malin Deman, te verdringeu door stichtelijke, d.w. z. door geschriften, gegrond op de eene of andere vertelling uit de heilige overleveringen, en waarin dus God, de profeet, enz., te pas gebracht konden worden, en de wondermacht van den Islam kon worden verheerlijkt. In hoeverre nu die malim aan het oorspronkelijke verhaal omtrent Salomo, verondersteld dat hij er werkelijk een had gehad, getrouw gebleven is, valt moeielijk na te gaan. Hij-zelf geeft te kennen, er wat aan toegevoegd en wat van weggelaten te hebben. Zeker echter is het, dat men in de Poeteri Balkis veel vindt, dat, als geheel aan het leven van den Minangkabauer ontleend, ook in andere legenden van dat volk wordt aangetroffen. Gaat men b. v. na, welke bovennatuurlijke eigenschappen aan den Toeankoe in de Tjindoer Mato worden toegeschreven, dan valt het te begrijpen, dat bedoelde malim Salomo, dien hij een profeet Gods, den belijder van het ware geloof, van den Islam, noemt, tevens kan voorstellen als iemand, die gebiedt over alle schepselen op aarde, over het geheele geestenrijk, over wind en weder, en die zich als afgezant bedient van een pauw, wier bovennatuurlijke eigenschappen aan eene heidensche opvatting doen denken. - Bedoelde voorbeelden uit de Poeteri Balkis mocht ik, mijns inziens, dus wel gebruiken, to meer omdat er van dien aard in menigte, ook in andere Minangkabausche verhalen, gevonden worden, 
zich over het algemeen de zon als iets krachtigs of mannelijks voorstelt, de maan daarentegen het zachte, het vrouwelijke vertegenwoordigt, men vindt deze opvatting ook terug in de verklaring; die de Minangkabauer hier en daar van den droom eener zwangere vrouw pleegt te geven, die, als zij in haar slaap de zon ziet, een zoon, wanneer zij de maan aanschouwt, een dochter ter wereld zal brengen.

Bij de behandeling van de mythe van het huwelijk van hemel en aarde, spreekt Dr. Wilken ook over regenbezweringen. Dergelijke bezweringen - het zij hier terloops opgemerkt - komen ook bij de Minangkabauers voor. Zoo bestaat in het Soloksche, naar men mij verhaalde, de gewoonte, dat bij eene langdurige droogte eene menigte halfnaakte vrouwen zich met een onnoozelen man naar de rivier begeven en hem daar, al stoeiende, met water begieten, hierin een middel ziende om den regen af te dwingen. Somtijds nemen de vrouwen een zwarte kat mede, welk dier men onder water houdt of laat rondzwemmen, om het daarna, als het aan den wal gekomen is, onder luid getier, net water na te gooien. Deze ceremonie is bekend onder den naam van basimboeă simboeă a i ĕ $=$ elkander met water begieten. Elders weer gaan er, als het lang droog geweest is, eene menigte vrouwen onder begeleiding van muziekinstrumenten en het aanroepen van Allah om en door het dorp heen. Meer algemeen is echter het zoogenaamde $\mathrm{m}$ anja rang $\mathrm{h}$ a ri. Onder de Minangkabauers komen er n. l. personen voor, van wie men gelooft, dat zij het weder kunnen bezweren, d. i. zoowel aanhoudende regens als langdurige droogte kunnen doen ophouden. Het middel, dat zij daartoe aanwenden, is een tooverformule en een benzoë-offer. Een tiental jaren geleden en kort voor mijn vertrek van Fort de Kock, was ik getuige van eene dergelijke bezwering. Er zou n.l. een groote buitenpartij gehouden worden, waarvoor, op eenigen afstand van genoemde plaats, een ruime loods voor de genoodigden was opgeslagen. Verscheidene dagen achtereen waren er regens gevallen, zooals men die alleen in de tropen ziet, zoodat men er over begon te spreken, de verdere toebereidselen voor het feest te staken, uit vrees dat dit toch mislukken zou. Het Maleische Hoofd echter - wij zullen ons onthouden 's mans naam te noemen -drong er op aan, dat men zich zou houden aan hetgeen bepaald was en op den aangegeven dag feest zou vieren. Den avond vóór dien dag, viel het water bij stroomen uit den hemel, maar in die oogenblikken werd er ook geofferd, om het weder tot bedaren te brengen, en - o, wonder! - den daarop volgenden morgen 
ging het gezelschap, bij een vriendelijken zonneschijn, welgemoed het gebergte in. Wat de kroon op het werk zette, was, dat de sluizen des hemels zich weer met nieuwe kracht openden, zoodra, bij het huiswaarts keeren, de eerste ruiter te paard gestegen was. Een anderen keer, toen men eenigen tijd achtereen gezwoegd had onder eene verzengende hitte, vond ik, op het oogenblik dat ik den man een bezoek bracht, in een hoekje van de voorgalerij zijner woning een potje benzoë staan. Hij-zelf was dicht daarbij op den grond gehurkt en scheen te droomen. Toen ik hem vroeg, waarvoor die benzoë gebrand werd, begon hij te glimlachen, en antwoordde met het; gewone in $\mathrm{da}^{\varsigma}$ toea $\mathrm{n}$, dat is: "'t is niets , mijnheer!" Op mijn aandringen en dat mijner medebezoekers, allen Maleiers, vertelde hịj mij, met denzelfden glimlach, dat het was om te manja rang hari.

Dat door den Minangkabauer een persoonlijk aanzijn ook aan andere natuurvoorwerpen wordt toegekend, en in verband daarmede deze mannelijk of vrouwelijk gedacht worden, moge hier nog met een paar voorbeelden worden aangetoond. In de eerste plaats wijzen wij op den zoogenaamden batoe barana ${ }^{s}$, een steen wiens vorm van dien aard is, dat het schijnt alsof er een kleinere aan is vastgehecht. De meening is, dat deze kleinere uit den grootere is voortgekomen, zooals wij reeds bespeuren kumnen uit den naam ba ran a ${ }^{\varsigma}=$ met een kind, een kind krijgende, een kind barende, zijn. Zoo ook bestaat omtrent de bergen Marapi en Singgalang de volgende legende: De bergreeks, waartoe deze twee gevaarten behooren, was in vroeger tijden, zoo vertelt de Minangkabauer, verbonden met die, waaruit de Pasaman zich verheft. Die drie toppen waren toen de beste vrienden ter wereld, maar de eerste en laatste vatten gelijktijdig eene vurige liefde op voor hun schoone vriendin de Singgalang. Minnenijd was nu de oorzak van eene hevige uitbarsting der beide reuzen: het tusschenliggende landschap werd daardoor met steenklompen overdekt en door diepe ravijnen doorsneden; de keten, die hen samen had gehouden, was voorgoed verbroken. De Marapi was overwinnaar gebleven en vierde met zijn geliefde den bruiloftsnacht, tengevolge waarvan de Singgalang nog immer zwanger is, waarmede de Minangkabauer bedoelt, dat deze vulkaan nog zijn eerste* uitbarsting moet ondergaan ${ }^{1}$.

1 De eerste bevalling, d. i. de eerste uitbarsting, van den Singgalang zal, volgens sommigen, ook voor ons Nederlanders belangrijk wezen, daar onze heerschappij op Sumatra dan een einde nemen zal. 
Wij hebben ten slotte nog na te gaan, wat er bij den Minangkabauer valt op te merken omtrent het spiritisme, de vereering van onzichtbare, vrij rondwarende geesten, en wel in de eerste plaats van de zielen der afgestorvenen.

Wat betreft de geesten van beroemde voorouders of van personen, die om de eene of andere reden eenen naam onder de bevolking verworven hebben, zij worden geacht op 's menschen leven een grooten invloed nit te oefenen. Onder hen bekleeden de zielen van de stichters eener negori of van de stamvaders eener familie eene voorname plaats. Tegenwoordig brengt men er ook de zielen van beroemde sjaichs toe. Gewoonlijk treden zij als beschermers op, wanneer gevaar of onheil dreigt, of zijn zij krachtige medewerkers, waar men zich voorstelt eenig plan te volvoeren of aan eene vrome of heilige bedoeling gevolg te geven. Daarom is het dan ook, dat zij naast Allah en den grooten profeet in het gebed aangeroepen worden, zooals o. a. blijkt in de legende van Soetan Manangkérang, waar Andam Dewi aan den herder vraagt, om haar moendam uit het water te halen, en waar men leest: Laloe diambiě malah api, taga ${ }^{5}$ a djoengoei tabiěng tinggi di panggang koemajan poetiěh, karatan koemajan baroeih, mamantang injŏkagoenoeăng, mangadap injŏ ka bilat, didjoedjoeăng djari nan sapoeloeăh, manjaroe injŏ disanan: barakat nènè djŏ moejang, barakat ajah djŏ boendŏ, ajah dèn lai asa radjŏ mandé den lai asa poeti, baramboeihlah angin dari tangah toelas kan moendam katapi, d. i. : "Vervolgens nam zij vuur, ging aan den uithoek van een hoogen afgrond staan, stak een stukje benzoë van Baros aan, en sprak, terwijl zij, met het gezicht naar het Westen gekeerd en de handen op het hoofd gevouwen, naar de bergen blikte: "Ik smeek U (zij bidt tot God en de Heiligen, mamintas padǒ Allah bakaoeă tantang fian kiramat) laat door de heiligheid mijner voorouders en ook door die mijner ouders, welke beiden van vorstelijke afkomst zijn, de zeewind mijn moendam naar het strand drijven !" 1 Een dergelijk voorbeeld vindt men ook in de Mandjau Ari, waar Moerai Randai afscheid neemt van hare woning en bidt: "Ik smeek dit aan $U$ en Moehamad, ter wille van de macht en de grootheid mijner voorvaderen, die begraven liggen op den heiligen berg Ledang, en aan wie, zoowel bij hun leven als

1 De regels van dit gedeelte zijn in de editie van den Soetan Manangkerang eeniçszins verkeerd geplaatst en moeten volgen zooals hierboven. 
na hun dood, zij, die eene gelofte hadden afgelegd, hun offers brachten". De plaats, waar die geesten worden aangeroepen, zijn over het algemeen de tampat kiramat, de heilige graven. Men vindt ze meestal op den top van een heuvel of berg, overschaduwd door een of meer groote baringin-boomen. $\mathrm{Zij}$, die de hulp dier machten willen inroepen of die willen voldoen aan hetgeen zij vroeger beloofd hebben, gaan gewoonlijk onder aanvoering van een priester er heen, om te offeren en te bidden. Het offer is veelal een dier, dat buitengewone kenteekenen heeft, b. v. een geit of schaap met een witten ring om het lichaam. Dikwijls ook bepaalt men zich tot bidden, en bestaat de offerande alleen uit eenig geld, dat aan den priester geschonken wordt.

Wat betreft de geesten van hen, die pas gestorven zijn, aanbidding van dezen bestaat bij den Minangkabauer niet. Toch wordt er, voornamelijk gedurende den tijd, dien zij geacht worden nog op aarde te zijn - wij zagen dat hierboven - met grooten eerbied aan hen gedacht en bestaat de voorstelling, dat men hen zoowel vertoornen als gunstig voor zich stemmen kan. Zoo sluit zich het menschdier bij den meest geliefde onder zijne bloedverwanten aan en treedt beschermend voor hem op, en is de ziel vijandig gezind, waar twist en tweespalt haar verhinderen, de woning der haren te bezoeken.

Bij de vereering van de afgestorvenen makt de Minangkabauer geen gebruik van beelden, zooals dit het geval is bij andere stammen in den Archipel, en evenmin bedient hij zich, tot een gemakkelijker verkeer met hen, van lichamelijke overblijfselen. Bedenkt men echter, dat de Minangkabauer zich door den Islam verboden ziet eenige teekening of schilderij, anders dan die betrekking heeft op dezen godsdienst, in zijne woning te hebben, dan is het voor niet onwaarschijnlijk te houden, dat ook hier de voorvaderlijke gewoonten door vreemden invloed langzamerhand verloren zijn gegaan. Dat aan eenig lichamelijk overblijfsel van een afgestorvene bovennatuurlijke kracht wordt toegeschreven, dat dit als medium tusschen mensch en geest dienst kan doen, is ons o. a. gebleken in het hierboven medegedeelde omtrent het toovermiddel om de $\mathrm{Si} D \mathrm{Djoendai}$ te verwekken, waarbij van het voorhoofdsbeen van een overleden held gebruik gemaakt wordt. Evenzoo verhaalt de Heer Van Hasselt, hoe men zich, in het geval dat eene ziekte beschouwd wordt het gevolg van eenig boos opzet te zijn, bedient van een gasiěng tangkoera oerang mati badarah, d. i.: een schijf uit den 
schedel van een mensch, die een bloedigen dood gestorven is. Op eene vereering van lichamelijke overblijfselen wijst misschien nog eene mededeeling in den Soetan Manangkerang, waar het afscheid beschreven wordt, dat de held van het verhaal van zijne ouders neemt, om zijne zuster Andam Devi te gaan zoeken. Zich voorstellende, dat hị de ouderlijke woning niet zal wederzien, geeft hij zijn vader een haarlok, waarvan de gedurige aanschouwing de gedachte aan den afwezige levendig moet houden ${ }^{1}$.

Dat de reliekenvereering daarentegen in zekeren zin nog onder de Minangkabauers wordt aangetroflen, is reeds gezegd bij de behandeling van het fetissisme. $\mathrm{Nu}$ eens om hunne bovennatuurlijke afkomst, dan weder dewijl zij erfstukken zijn van beroemde vorsten of heiligen, meestal wegens hun bijzonder maaksel en hunne eigenschappen, die geheel van de natuurlijke afwijken, zijn zaken, die aan de voorouders toebehoord hebhen, voorwerpen van vereering geworden, die men alleen met reukoffers en gebeden naderen mag.

Tot dusvere beschouwden wij de geesten, die voor de menschheid eene vriendelijke, liefderijke geaardheid aan den dag leggen. Gaan wij nu na, wat er verteld wordt van hen, die, volgens den Minangkabauer, den mensch kwalijk gezind zijn.

Evenals de andere stammen in den Archipel aan de pontianak, gelooven de Minangkabauers aan den Si Koenias, den natuurlijken vijand van het mannelijk geslacht. Als eene zwangere vrouw - zoo vertelt men omtrent het ontstaan van dit wezen - haar kind heeft afgedreven en dit in het bosch of elders doet begraven, blijft de geest van het ongeboren schepsel op die plaats rondzwerven in de gedaante van een kikvorsch. Deze toont zich een verbitterd vijjand te zijn van alle mannen, doch in het bijzonder van zijn vader, wien hij, zoo hij daartoe kans ziet, bij de genitalien grijpt, welke hij niet loslaat, voordat hij hem die van 't lichaam heeft gescheurd. Men noemt dezen boozen geest, die, zooals men zegt, als een klein kind schreeuwt, ook wel koenjia of kankoeăng ngeas. Verder hoorde ik vertellen van een spook, dat onder den naam van Si Sindai of Si Tjindai voorkomt, en onstaat nit vrouwen, die een dood kind ter wereld brengen, of wier kind, onmiddelijk na de geboorte, sterft, en die, tengevolge van hare groote droef heid daarover, zelve sterven. Ook deze geesten hebben een grooten afkeer van de mannen, die

${ }^{1}$ Bij het bovengenoemde manggasiěng doet het harr van een nog in leven zijnde persoon dienst.

Бе Volgr. V. 
zij in de duisternis overvallen en hun de genitalia afrukken ${ }^{1}$. Aan de pontianak beantwoordt ook een spook, dat gezegd wordt er uit te zien als een schoone vrouw met lange, loshangende haren. Niet alleen zou zij de mannen haten en kwellen, doch ook pasgeboren kinderen. Volgens de opvatting is het de ziel van eene vrouw, die, tijdens haar huwelijk, in overspel leefde, en stierf, op het oogenblik dat het kind, de vrucht harer zonde, het leven zag 2. Vrouwen integendeel, die gedurende hare zwangerschap sterven, komen onvoorwaardelijk in de sorga, den hemel, hetgeen ook het geval is met doodgeboren en jonggestorven kinderen, die eene plaats krijgen in de wiegjes onder den bovengenoemden baringin sonsang.

Behalve de zielen der afgestorvenen, kennen de Minangkabauers nog eene menigte andere geesten, die, als wij het zoo eens mogen uitdrukken, meer het eigenlijke godendom vormen. Gaan wij echter eerst na, hoe de Minangkabauer zich het heelal voorstelt. De lezer kan zelf oordeelen, waar men met begrippen van den Islam te doen heeft.

De aarde is een platte schijf, rustende op de puntige horens van een vervaarlijk groot rund. Dit dier staat op een ei, dat gelegen is op den rug van een visch, die rondzwemt langs de oppervlakte van de onmetelijke wereldzee. Onder die zee is niets meer en heerscht eene dikke duisternis. Wanneer eenig insect de onbeschaamdheid heeft, zich een rustplaats te kiezen in het oor van dat rund, schudt dit dier den kop en de aarde beeft.

Wanneer de donder rolt, zijn de engelen vertoornd op de dichte drommen van geesten, die elkander in het luchtruim verdringen, en van wie zij de meest vermetelen door geweerschoten terugdrijven. In zeven stukken verdeeld, vallen de getroffenen ter aarde, maar uit elk deel groeit een nieuwe geest, en zoo vermeerdert het aantal duivelen zevenvoudig. Het vuurwapen, waarmede geschoten werd, springt uitelkander, en de splinters daarvan richten vernieling aan onder menschen en dieren, boomen en gebouwen.

Het bliksemt. Het helle licht, dat in afgebroken richting het zwerk doorklieft, is de weerglans van de reuzenzweep, waarmede de malaikats, de engelen, de oproerige geesten kastijden.

Hoog boven bergen en wouden strekt zich het vriendelijk blauw

1 Anderen zeggen dat Si Tjindai de naam is van een ziekteversohijnsel, dat veel overeenkomst heeft met de Si Djoendai, en zich vertoont bij moeders, die haar kind verloren hebben, of bij vrouwen, die langen tijd aan hevige koortsen hebben geleden.

${ }^{2}$ De naam van dit spook is mij ontgaan. 
uit van het heerlijke gewelf, dat de schoonheden des hemels voor het menschelijk oog verborgen houdt. In zeven verdiepingen is het opgebouwd van de schoonste stoffen, die heerlijker en kostbaarder worden naarmate men nadert tot het verblijf, waar Allah, de oppergeest, op zijn troon zetelt, samengesteld uit de schitterendste diamanten.

Het blauwe koepeldak is de helft van een zilveren bol, waarop millioenen fakkels hun glans weerkaatsen, ter verlichting van het aardrijk. Tal van engelen zwerven daar rond als wachters aan de pintoe's (poorten), door welke de zielen geleid worden voor den troon des Allerhoogsten. De zon, uit louter vuur bestaande, wordt er door hemelnimfen in blinkend gewaad voortbewogen, onder den jubelzang van lâ ilaha illâ 'llah, d. i.: er is geen God dan Allah.

In het zilverlicht van de platte maanschijf spiegelt zich de schaduw af van een reuzenbaringin, wiens bovenste bladerenvlakte naar beneden is gekeerd. In de koele schaduw van dien reus jubelen en dartelen de bidadari's, de overschoone vrouwelijke hemellingen - totdat zij, spelensmoede, zich ter ruste vleien in sierlijke wiegen, zoo duidelijk zichtbaar als men, bij volle maan, door een zijden doek de nachtvorstin aanschouwt.

Zon en maan kunnen evenzeer als gewone menschenkinderen lijden, en waar zij ziek zijn, vertoonen zij zich in den somberen sluier, dien wij verduistering heeten, en die de harten met zooveel schrik en angst vervult ${ }^{1}$.

Boven het zilveren hemelgewelf strekt zich eene onmetelijke zee uit, en wanneer het aardrijk dorst, ontstaat er in dat gewelf een tal van openingen, waardoor een weldadige regen akkers en velden beproeit.

In dat groote heelal nu leven talrijke geesten. Allah, de Schepper, - de Toeankoe koeasǒ, d. i.: de machtige Heer, zooals hij volgens den Heer Van Hasselt door sommigen wordt genoemd is de oppergebieder. Alle anderen zijn zijne dienaren. Zij zweven door het luchtruim boven bosschen, velden, bergen en wateren, houden zich op in spleten en spelonken, en bewonen de toppen van hooge boomen zoowel als de bronnen en putten; zij zijn om en

1 De Minangkabauer spreekt van boelan en matohari sakiء. Sommigen noemen als oorzak van dit natuurverschijnsel de garoed os, een draak met zeven koppen, die de bollen geheel of gedeeltelijk inslikt. Deze opvatting komt mij echter voor van vreemden oorsprong te eijn. 